University of Louisville

ThinkIR: The University of Louisville's Institutional Repository

\title{
Adair, then and now : an example of cooperation between school and community as seen in the Adair School District (Elementary School No. 78-2) Jefferson County, Kentucky.
}

Emma Nisbet Whalin 1900-1960

University of Louisville

Follow this and additional works at: https://ir.library.louisville.edu/etd

Part of the Education Commons

\section{Recommended Citation}

Whalin, Emma Nisbet 1900-1960, "Adair, then and now : an example of cooperation between school and community as seen in the Adair School District (Elementary School No. 78-2) Jefferson County, Kentucky." (1949). Electronic Theses and Dissertations. Paper 2202.

https://doi.org/10.18297/etd/2202

This Master's Thesis is brought to you for free and open access by ThinkIR: The University of Louisville's Institutional Repository. It has been accepted for inclusion in Electronic Theses and Dissertations by an authorized administrator of ThinkIR: The University of Louisville's Institutional Repository. This title appears here courtesy of the author, who has retained all other copyrights. For more information, please contact thinkir@louisville.edu. 
UN IVERSITY OF LOUISVILIE

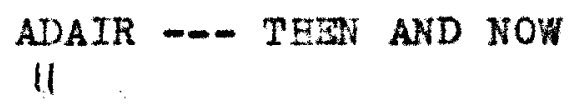

AN EXAMPLE OF COOPERATION BETWEEN SCHOOL AND COMUUUITY AS SEEN IN THE ADAIR SCHOOL DISTRICT

\author{
(BLIMUATART SCHOOL NO. 78-2) \\ JEPFERSON COUNTY, KENTUCKY \\ A Professional Paper Submitted \\ to the Faculty of the Graduate school \\ of the University of Loulsvilie \\ In Partial Fulfillment of the Requirements \\ for the Degree of Waster in Education
}

Department or sducation

by

Emma Nisbet whal in

1949 
This PDF document is a scanned copy of a paper manuscript housed in the University of Louisville (UofL) Libraries. The quality of this reproduction is greatly dependent upon the condition of the original paper copy. Indistinct print and poor quality illustrations are a direct reflection of the quality of materials that are available for scanning. The UofL Libraries greatly appreciates any better copies that can be made available for replacement scans. 
DEDICATED

TO

MY SON. CHARLS R. WHALIM

AND

DAUGHER, MARTFA LOUISE WFALIN

AND LAST BUT NOT LEAST

TO THE YOUT OF THE ADAIR COMMNITY

AND THEIR PARENTS 


\section{ACTHOR'S ACKNOWLEDOMENT}

The author wishes to express her sincere appreciation to all those who helped in any way in making this paper posslole -- parents, teachers, chllaron and others. She especlally ishes to thank Superintendent orville J. Stivers of the Jefferson county Doard of Education for supplyine information in regard to the oarly blstory of the school; and the many residents of the community who eraclously contributed information in regard to the early history of the comunity. Sho also wishes to thank $3 . D$. Nisbet for his stimulating sugeestions which were extremely valuable in writing this paper; $D$. F. Nisbet, who made the photostatic coples found in thls paper and Iss Adelalde F. Eostick, who helped to organize the material and revised the manuscript. 
NAWE OF STULDNT:

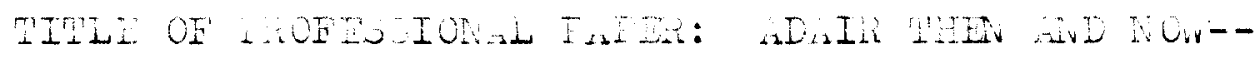

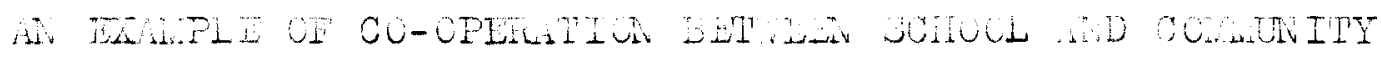

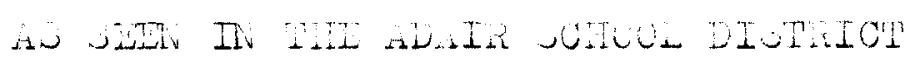

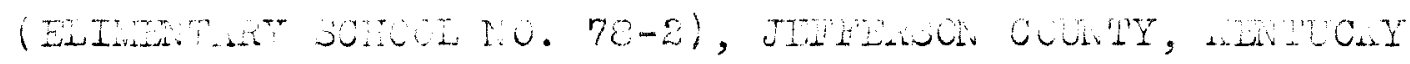

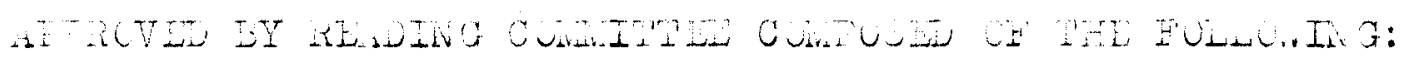

Clyde W. Swink

Guy Stevenson

NAW WIREOS Uג: J. J. J. Oppenheimer

D.2.: Gug, 11 1949 
INTRODUCPION

I. Purpose of thls Paper.......... 2

A. To Show Developmont of school and Commity, "Adalr Then" . . . . 2

B. To Show present folationship of school and Community, "Adair Mow" . 2

II. Basic fosumptions underlying this paper. 2

A. That Education is part of Ifie Itself ........... 2

B. That a cood School Providea Opportunities for Experlences Conduclve to Growth ....... 3

c. That a cood school is Democratic . 4

D. That the Small community School Affords Exeolient opportunities for Fenocratic Living....... 4

\section{PART I -- "ADAIR THEY"}

I. Physical properties of the community . . 8

A. Description of Location and

Boundarles ........ 8

3. Soll and Dralnage ....... 8

C. Roads and ransportation ..... 9

II. Early History of the Communlty .... 10

A. Description of "Shardine Precinct". 20

B. Early Ploneers ........ 11

1. Jenken PhIllips ..... 12

2. Dr. E. D. Standford ... 18

c. Summary of Interview with oldest lesident ......... 19 
III. Early Elatory of the school ...... 22

A. Johns School, Ponated by Mrs. Rector Johns in $1925 \ldots 23$

1. Bullalng of school ....24

2. Trlbute to Mrs. Rector Johns. 24

B. Two-teacher school, 1928-1936 . . 27

C. Change of llame to "prestonia ⿰氵. 2,1930 ........ 27

D. Pour-taacher school, 1936-1938 . 28

E. Change of Name to "Adalr School" 1936 .............. 28

F. Addition of Two-room Portable, 193828

G. Continuing as Five-teacher School to $1949 . \ldots . . . .29$

H. Creation of Separate District, "Adalr No. 70-2", 1941 ..... 29

IV. Zarly vxamples of Comunity-and-School

cooperation .......... 29

A. Provision of Free lunch . . . . 29

1. Iy Prestonia P.T.A. .... 29

2. $\mathrm{By}$. and Mrs. Roy Collins. 29

B. Annual cift of Christmas pree...30

c. Award from County Health Department ........ 32

D. Response of School and Community in Tines of Disaster - 1937 Flood . 33

v. Junlor ged cross ketivities turing Jorld har II ........ 34

PART II -- "ADAIR NOW"

I. Present School Plant and Personnel . . 37

A. Bullaing ......... 37 
1. St11l only Five Classrooms ........ 37

2. Wethod of Taking care of Increasing Number of Puplls by Transfer to other schools .. 37

3. Equipment of classrooms ... 37

E. Personnel . . . . . . 38

1. Faculty ...... 38

2. Custodian ....... 38

c. Lunchroom . . . . . . . 39

1. Deglaning and Equipment of Lunchroom .......40 40

2. Present runctioning of Lunchroom ......... 40

3. Hethod of Handling ree Lunches ........ 40

II. Parents' Cooperation with the school . 4 41 A. Organization of P.T.A., 1945 ...4 41

B. Wethods of Financing P.T.A. work . 42

C. Accomplishments of P.T.A. . . . . 42

D. Contributions of Individuel parents 44

1. "Room Nothers" ......44

2. Fathors........ 45

III. Commity Jenefits from Outside

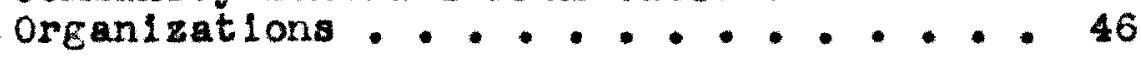

A. Necossity for Outside Ala .... 46

B. Jxamplas of Such ald . . . . 47

1. HLghland Park Plagground . 47

2. Optimist Boys' Club .... 47

C. Value of These organizations ...48 
IV. The school Training children to bo Good Citlzens of the communits...... 49

4. Training in Health and futrition, 49

1. Pre-school clinles ....49 49

2. Immunlzations . . . . . 49

3. Vutrition Education .... 50

B. rainine ln safety ...... 51

1. Safoty walk on Highway ... 51

2. Discussion of Fire

provention ...... 52

C. Training in Conservation .... 52

1. "Eutton Project" ..... 53

2. Vending kit to Encourage Care of Clothes ....... 53

D. Training in soclal situations... 55

1. Planning Valentine farty ..55

2. aklng Table Decorations . 55

3. Praparing Hot Chocolate... 56

4. Entertaining a visitor . . 56

E. Trainine in observation and

Appreclation of vature ..... 57

1. "Sclence Corner" ..... 57

2. Cecropla loth..... 58

3. "Pet Day" . . . . . . . 59

F. Falning in appreciation of the ir

Cwn itato......... 59

1. Liscussion of places of Interest in rentucky .... 59

2. Waking of Kentucky scrapbook ....... 60 
a. Introduc ing chlicren to National

Interests ...............

1. Plctures of President and Vice-president ........

2. "riting of Letter to vicepresident..........

3. Receipt of inswer from :10epresident............

4. Simllar ixchange of Le ters wth president ......

5. Interest in vaster Seal campaign Plcture of $71 \mathrm{co-}$ President Barkley and Chlld Who Had Visited Valentine party

I. Devoloping Appreclation for other States and countries

1. Souverirs fron other states.

2. Souvenirs from Alasika and Hawa11 . ......... 69

3. Ioan Exhlbit of Japanese Imporial iolls

I. Doveloping Appraclation iy School Excursions ..........

1. Excursions of Primary Grades to Dalries .........

2. Irip of pirst and second crades on Traín ........

3. Irip of Samo Grades heross onlo Rlver ..........

4. Trip of Fourth and Fifth Grades to Courler-Journal Eullalng . . . . . . . .

5. Ir Ip of Same crades to Library and Central Park ...... 
$\underline{\text { Page }}$

J. Doveloplng a Sense of Splritual

Values.............. 74

1. No Separate Tine for toral snd Spiritual Trainine. . . 74

2. Attempt to Develop Such Values in All of School Activitios..........

3. Encouraement of Attendance at Church of Puplls' own Cholce.......... 75

4. Practice in Returning Thanks 75

5. Meriorlzing of BlUle Passages 75

CONCLUSION

I. Continuing Changes and icjustments in School and community . . . . . . . 77

A. Aajustments in the past .... 77

B. Prospective Adjustments for tho

Duture.............. 78

II. Reasons for continuing to Teach in a

Small Comaunity School......... . 78

A. Heeds of the Small community ... 78

B. Opportun1ties in the Small Community ........... 79 
Nap of Adair School District and Community . . 7 plcture of 0ld PhIllips Homestead ...... 17 Elcture of urs. Rector Johns ....... 26 Photostatic Copy of Puplis' Letter to VicePresident Barkley ........... 84 Protostatic Copy of Vice-President's Reply... 66 Photostatic Copy of iater seal Bulletin... 68 
IVTRODCCW IOH 
Introduction

The purpose of this paper is to describe the or1Bin and development of a specific small school in a speciflc small community, to show how the achool and the comunity cooperate with one another, and to present the relationshlp between this school and this community as an example of the democratic way of 11 fo on the local level.

The school is Adalr (Elementary School 1:0. 78-2) and the community is a small section of Jefferson county just outslde the city Iinits of Loulsville. The first part of the paper -- "Adalr mhon" - tells hov the nood for a school arose in this community; how this need was met by public-spirited cltizens of the comunity; and how, as the community expanded in population, the school grew Ith it. The second part of the paper -- "Adair Now" -- describes the present relationship betweon the school and the community, and ahows how they work tozother democratlcally for the good of all.

In treating of this school and this community, the witer shares the conviction of many modern oducators that education is no longer to be consldered as a preparation for $11 f e$ but as a part of life 1tself. Caswoll says:

1. Ceswell. Hollis $3 .$, Eucation in the Elementary School, p 100. 
Zducation is a continuous succession of one experlence after another which makes and remakes our ways of thinking, of feeling, or acting. Each new experlence contributes something to the process.

Thus education is Iife; it is a way of IIving in whlch one can make 11 fe more worth-whlle for himself and for those with whom he comes in contact. The purpose of $11 \mathrm{fo}$ is to give all one can, and not nerely that for which one has been pald. Adjustments must be made in Ilfe, and should bo made, in order to be helpful to others, since this is the true art of democratic Iiving.

Bducation is a growing process, since it is the process of accumulating knowlodge through experlence. since the chlld is constantly undergolne new oxperiences, not only within the school and the comnunity, but also in his individual life, this continulty of changes and experience constitutes the child's ilfe in the field of knowledge and education. A Eood school provldes experlences through which the child can grow and can learn to live the Eood 11fe; a good school creates the conditlons under which the pupll thinks for himself, and creates initiative under which the pupils begin to move on the ir om power. It creates conditions within the classroom where ach pupll can bo his peculiar or unlque self, and where the puplis 
can live together democraticaliy.

The home and the school of today have, to a large extent, outgrown the dlctator 1 al methods that formerly prevalled; and the principles of democracy are not only taught, but practiced in the good home and the cood school. The school is a place where puplis carry on a way of $11 \mathrm{fe}$, and every young person who leaves school should know the importance of particlpating in the Eovernent under whlch he 11ves. Any pup11, however brilliant in the fundamentals of sclence, art or other subjoct mattor, is atill serlously dericient, in his oducation, if he does not understand, and if he has not had opportunity to practice, this participation in the democratic way of 1190.

Among the cltizens of the smaller communitios, as well as in the schools, there is a growing tendency and desire to understand their civic, social and economic problams and to plan and work together in order to solve local problems. Before any leader or teacher can work constructively in any community, he must understand its social, oconomic and political situations. Ye zust know the attltudes and bellefs of the people; he must know their frlevances and their alficultios as well as their aspirations and their hopes for the future. In order to know these things, he must enter into the dally lives of the people and be received by them with complete confidence. The teachor of amall school in a small com- 
munity has an excelient opportunity for guch firsthand knowleage and entering into the lives of the people; and such teacher is in excellent position to work ith the people of the commity for improvoment and progress.

Good personal and human relations are the woof with which the tapestry of democratic Eovernment is woven. Democracy certainly is not cloak to bo wom just to cover the surface, or to be taken off and put on at w111. It goos much deoper than the surface. In the writer's oplnion, this small sohool and small community have been a Good example of democracy on the local level becaise the poople have had good human rolationahips with each other, and have worked together on the ir own initlative for the good of all. They have w111 Ingly shared of their resources and have worked unselfishly; they have tackled thelr own probloms with sincerity and airectness. At tho very boInning, this school had its oripin in the conerosity of a public-spirited citizen; and the samo gualitios of generosity and cooperation are still provaling today. 
PART I 

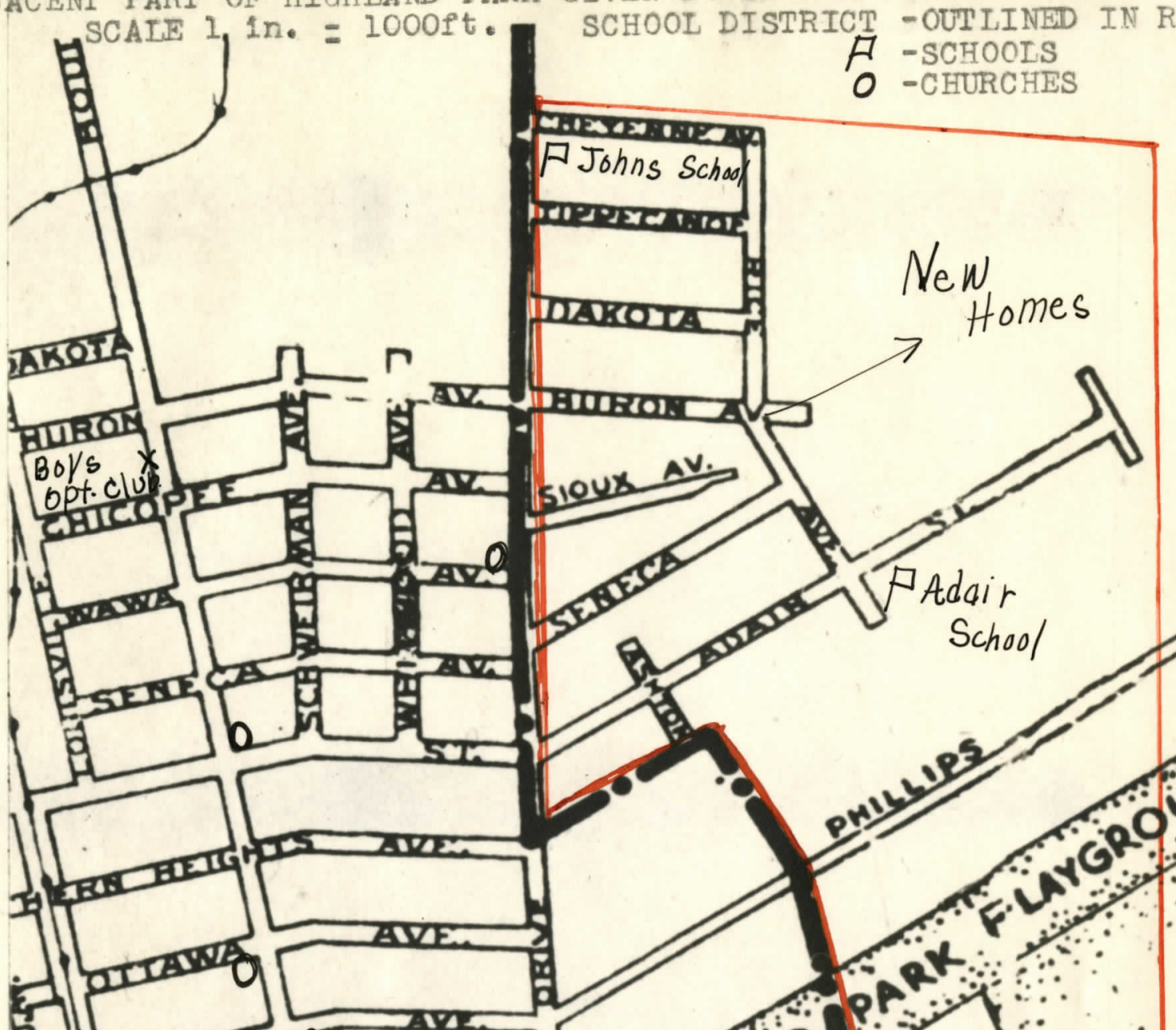

$A$
0 - - SCHOOLS

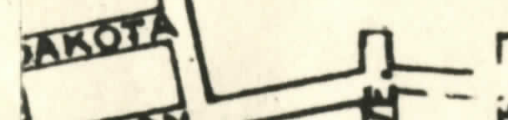

$$
1
$$
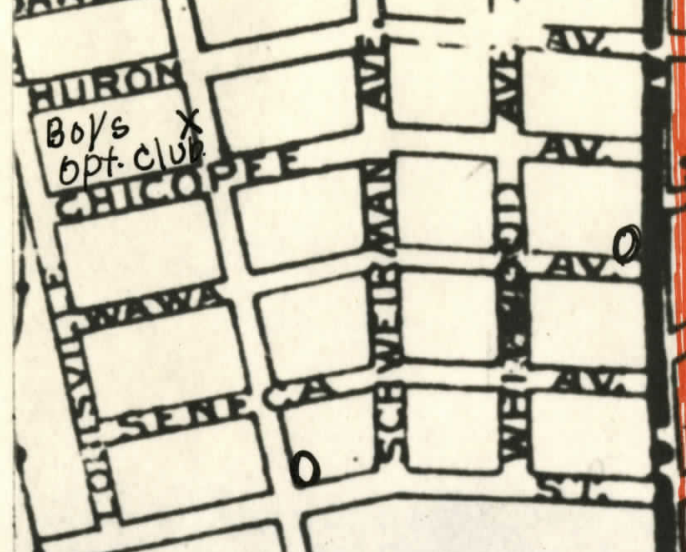

\section{4}

है क्या

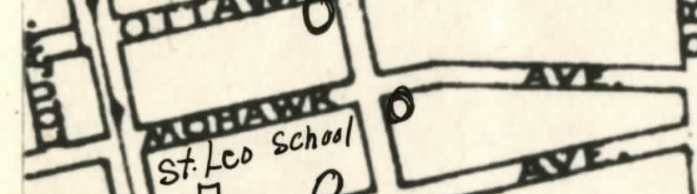

-].
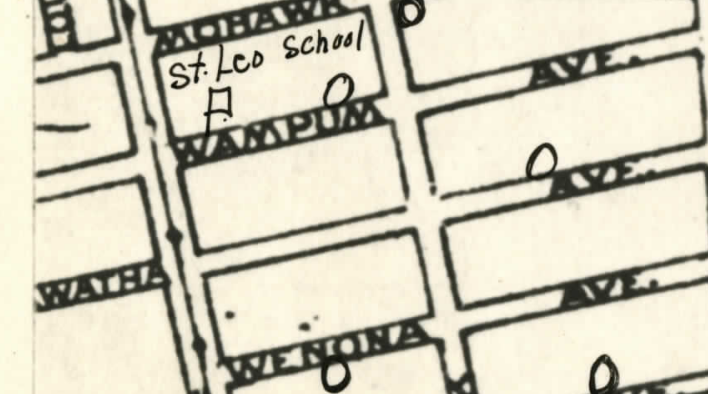

د
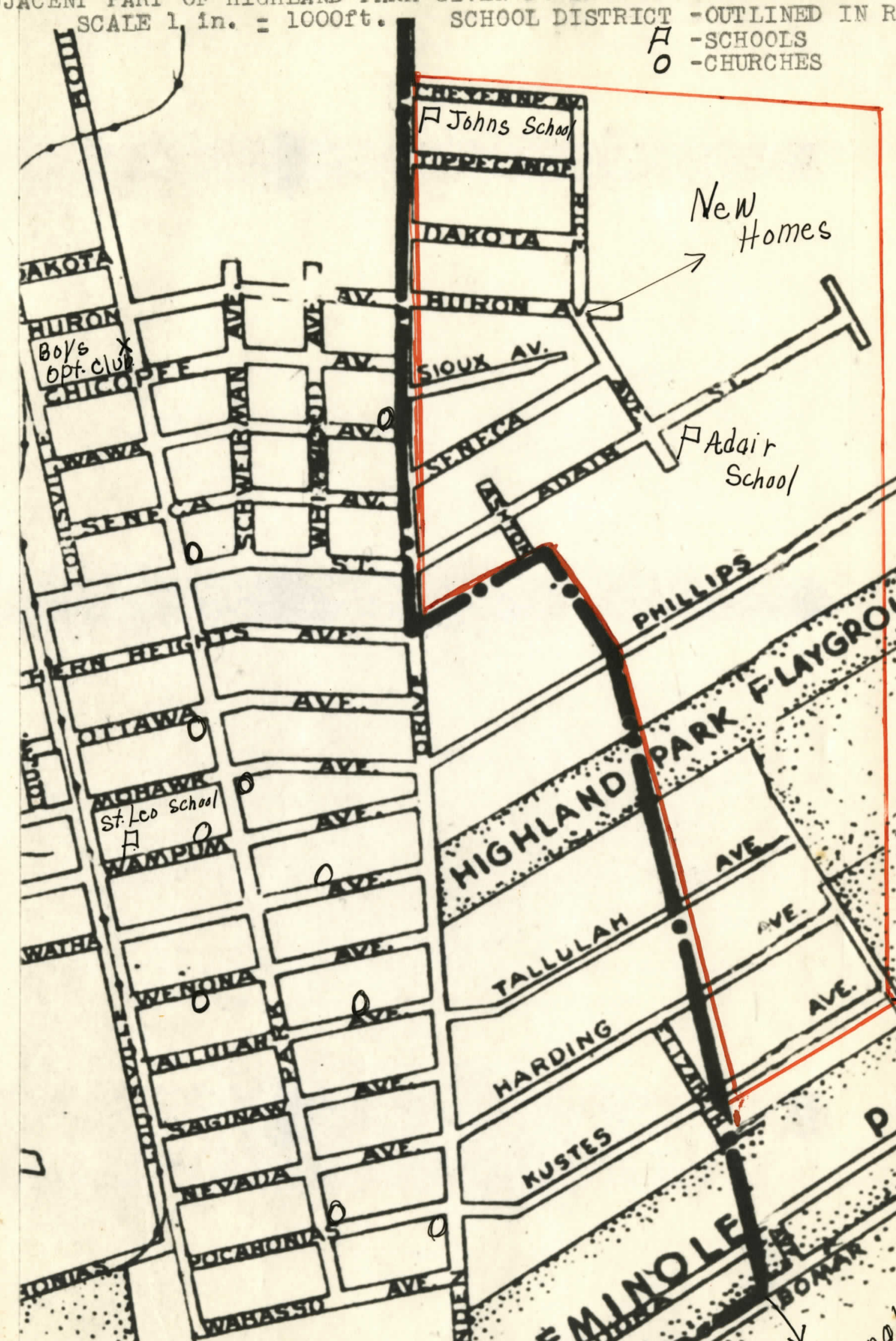


\section{PART I -- ADAIR THEN}

\section{Location}

The Adair School District is quite different from the average county school district. It is not considered elther rural or urban. It is in the county School system, in an area that was formerly a rich farming district; but it is as thickly settled as most parts of the eity and most of the people work at industrial plants elther in the adjacent section of the clty, known as Highland Park, or in the county.

The western boundary of the district extends to the city Iimits, as shown by the wide black line on the accompanying map. The nor them boundary includes Cheyenne Avenue and extends from the end of that avenue directly eastward until it is parallel with the end of Adair street. The eastern boundary extends in a southerly direction to Kustes Avenue; and the southern boundary includes Kustes Avenue. This is Immediately adjacent to HIghland Park and is practically one with It In social and business contacts; but the boundary Iine is clearly marked by the difference in streets and rosds; and Adair School and the not-so-far distant James Russell Lowell school are in two different school systems.

So11 and Drainage

In this area are found the remains of the deposit 
of the groat glaclal outwash. After the elacler, this area was fllled with huge boulders, on top of these massive rocks, a finer sediment of eravol and sand was 10ft. Th1s helped to form a compact crust on the surface that was difflcult for the water to seep through or draln off quickly. In order to ramedy this situation doap wells wero bored in this area and this helped to lower the water taible and thus made the land more productive for farming. In the early perloc of development, the land abounded. in pasture lands and grain.

The drainage of Jefferson county is by the Ohto Fiver, which follows the northest boundary of the County. Ml11 croek, whlch flows southwark, roughly parellel to the Ohlo Rlver and empties its volune of water near the southest corner of the county, drains this clacial area around Adalr. After a constant or hoavg rain, the watar is slow in araining off because of the type soll that it has to penetrate and also bocause this section of Jefferson county does not yet have an adequate dralnage system.

\section{Roads and Transportation}

Because of the facts presented above, sone of the un-improved streets and roads in this section are almost impasabie in wet wather. Crittencen brive, Fhllips Lane and Adalr streot have hard surface top. Kustes Avenue, rardine and Pallulah have gravel tops. 
he other short strects are located on what is referrod to as "Whe Hill" and are neither paved nor raveled.

Wost of the traffic in this section is routed by way of elther crittenden irlve or Phillips Lane. The Lo Isville Rallway Compang furnishes transportation to this area by means of the lilghland Park buses, which run on Flrst and Socond streets and also the International farvester buses by way of crittenden rive.

There are two rallroals in this section of Jefferson county: the southern, near the eastern boundary of this area and the Loulsville and Nashville, near the western boundary. Doth of these run in a southerly direction.

Early History of the community

This section of Jefferson County was formerly referrod to as the shardino precinct. This precinct was In the form of a triangle, wh its apex insice what are now the clty limits of Loulsvilie, bounded on the east by the southern Railroad and on the west by the Louisvilio and Nashvilio.

Its early history is considered to be more traditlonal than that of any other political division of Jefferson county. It was recorded that some of the

1. Wuch of the information on hlstory obtained from nistor of the oh10 Falls citles and Their CounEles, VoI. II. CompIled by I. A. TIIILams Co., Cleveland, ohio, 1882. 
aurliest gettlor: lost this aroa becalise tho land conditions ware not conduclvo to farming.

These once marshy and $30 \mathrm{cg}$ lands were afterwards settled by a thrifty, well-to-do cerman population who by their persistent and laborious efforts were able later to boast of highy cultivated farms and to live In a flourishing state. The complier of the Mistory of the ohio Falls cities and their counties, published in 1882, says of these Cermans:

They have settled in this portion of the county quite recently, comparatively, and will in course of timo have their lands all drained, and their farms fertlle and rich.

Thls prophec $\operatorname{cam} \theta$ true, and for many years of the IIneteanth and early Iwentleth Centurlos this was a rich farming area; in fact, it was not until orld war I that it began to be thickly settlod wh workers from Loulsville; and not until rorld war II that it becane Industriallzed with the bullaing of several large war plants.

\section{Early Ploneers}

Some of the arly settlers of this communtty who have left their nanes on the histerical records of time are as follows: "H. Alsmiller, tare, urnst, 3choar, Arbecust, Korfhaco, Calliger, Dr. W. Standirord, 
Jenken Phlllips, Kurray Ph1llips and others. Wang of the records of the early Inhabitants also record the number of acres they orned at the time. Tro of these early settlers whose storles are recorded in some detall are Jenken Phillips, born before the American Pevolution, and Dr. D. D. Standifora, born in 1831. Ph1111ps Lane, Phl111ps Avenue, Standiford Lane, and standiford ifport porpotuate these names in this aroa. Jenken Ph1111ps

Jonken PhIllips was born in Loudoun county, VIrElnia in 1761. He was a second-generation native of the American Colonies, for his father, Thomas Phillips, hed boon born at sea in 1717 while his family were en route to the New world. In 1776 , though only fifteen gears of age, Jenken Philips served with the Loudoun Military Company in the Fevolutionary war uncer the capable leadershlp of Ganeral George Washineton; and In 1778 he took the oath of alleglance to the undted States Government. As a reward for falthful service, many land grants were given by the state of Virginia to those who had served for certain length of time. Jenken PhIllips was generously rewardeci wth very large grants in what is now Rentucky.

The grant to Jenken Philips first mentions a tract of 1,350 acres near Green siver, and then continues: 
Also 2000 acres 6 miles southeast from palls of ohlo betwean a large Beavar fond and the knobbs, noar two miles from the falls. 1

This entry is dated 87 18, 1780. Soon after the war endod, Mr. Phillips and his wife, Hannah, with their many aervants ane personal belongenca, came to Jefferson county and located on tract of land in this vicinity. They made this long, tiresone, and arduous foumey in two-whelec oxcarts. At this tine all the land in this aroa was thickly covared with virgin forests; and the country resembled an Afrlcan jungle wth lts thlck underbrush of vines and brambles and labyrinth of paths wind ine here and there, inade by the wild anirals that were plentiful and froe to roan at $w 111$.

After arriving at the site of the grant in Jefferson county, wr. Phillips, with the holp of his regro slaves, set to work in clearing the forest; and after a fow years in more primitive dwellings, he bullt the large brick home that still stands on 1 ts orleinal site. The slaves cut the timber and made and firad the brick from the native clay. Several small cabins were built for the Negro slaves in the rear of the big house. The farm and home provided for nost of the

\footnotetext{
1. Entry 3ook A, Jefferson county clerk's offlce, Lou1svIIIe, K.., P 363. Other Information about the Philipg fanliy obtained from Lydan durrett, great-grandson of Jenken PhIllips.
} 
neods of the family. There was an $100-h o u s e$ in which huge blocks of lce were cut and stored during the winter seas on to last throuch the hot summer days. At the back there was an old ach in in whlch the ashes were placed so that sorp coul be rade for the fanlly use. They grew flax and made their own linens. Wuch hemp was also grown in this section, and large fields of hay and grain as well as tobacco. Candies were made from beeswax, obtalned from the honeycorab ralsed in the ir ow beantves; honey was used for sweoțening and sugar was considered quite a rarity. Such thines as could not be erown at home were quite expensive; a dose of calomel cost 30.00 and a mustard poultice tho same. The early setters wove the ir own carpets as well as their covericts and clotb for their clothes, using wild frults and walnuts to dye the fabrics.

During the clvil war, the Northern soldiers encamped in the fleld new by the phillips home, and they would often concregate in the large kitchen in such numbers that it was alfficult for the servants to prepare the meals. The family valuables and money wore entrusted to one of the old falthful negreservants during this time when the enemy was camplne so close at hand. Mr. shomas Phllilps, son of Jenken, was in Loulgville when tho now was announcod that Lincoln had sined the Bmanclpation proclamation. On reaching hove, he summoned his slaves and told thom that the vere a froe people, 
and were at 1 loenty to $g 0$ when and where they pleased; but the slaves seemed to recelve the newg with a tinge of regret, for they told their master it was not their wal to Leave.

At the death of $\mathrm{r}$. Thomas phillps in 1872, ho loft a large estate in botr land and money. The old records stress the fact that both $\mathrm{r}$. and ws. Phillips were from good stock; his ancestors, as had been shown, came from England, while hors were descendants of the French Fuguenots.

The accompanying picture shows the old Phillips tomestoad, which st111 stands on Ph11lips Iuane near Freston street and misch is now fully a century and a half old. The orleinal home had a small front porch just the lath of the outer facings of the front doors, but large enouch to accomodate a bench on elther side. When this front porct began to deterlorate, it was roplaced by a larger concrete one; and a smilar ono was built on the right side of the house, as shown in the picture. A large hallway extends the entire depth of the house, with two rooms on elther side; these rooms are very large, about elghteen by twenty feet. one of the rooms at the back is a summer kitchen. The second floor of the house may be reached elther from the front or from the right side, up largo winding stalrways. Wach room has a spacious rood fireplace with a mantle above it. The woodwork inside the house is sald to be 
of solid cherry.

There are many traditions about this house, though they cennot all be verisled by written records. It is ald that wen iafayotte visited America after the hevolution te care to this section of rartucky and was muck impressod 1 in the lmronse forests, in which le could see the posslolilty of the rich fams wich later replaced tho foreats. It $1 \mathrm{~s}$ also saic that Louls Prillppe slept in tilis house on the same trip to Amerlca whlch has been made fanous by tho plctures wich he Eave to the Bardatown Cathedral.

The old homestead pessed out of the ownership of the Ph1llips famlly about forty years ago. It is now a part of the aroa wich has boen purchased for the new state falr crounds; ara those who are interested in the preservation of historlcal landmarks ano concerned as to what w111 be the fate of this veneracle structure wich preserves so any of the rollcs of earlien day. the PhIllips fanily buryine eround is located between Freston street and Newbure foad, near the site of the offlcers Training Camp at Camp Zachary Taylor. 1

1. Kentucky state Iistorical Register. Fllson Club, Lovisvilie, K., p 400. 


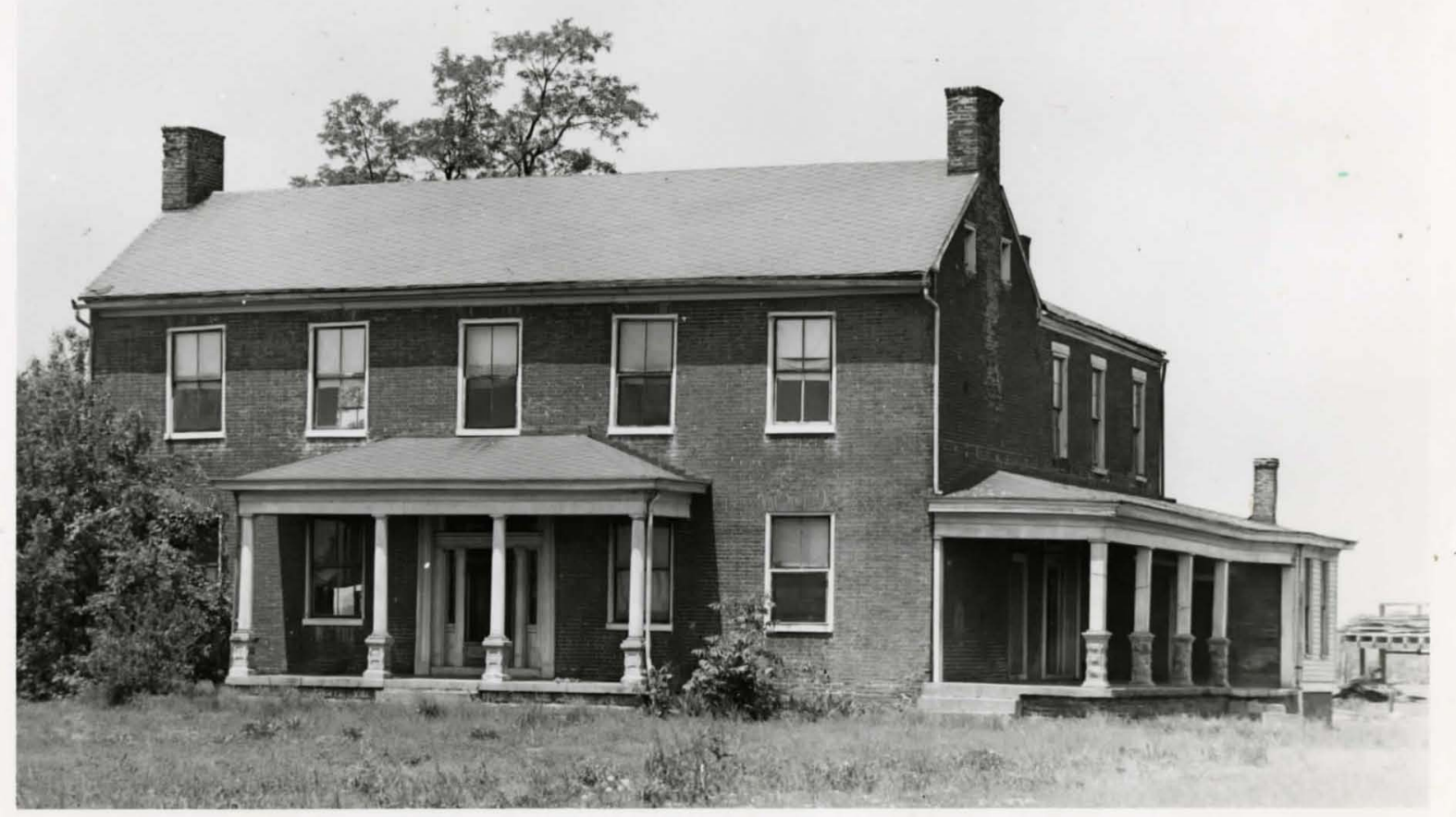

PHIIIIPS HOMESTEAD 
r. E. L. Etancisord

Dr. Ellsha Iavid Standiford was the son of Ellsha standiford, a successful farner whose ancestors came from switzerland and thence to varyland bofore settling in Rentucks. Dr. Standford's mother, hary rooks Standifori, belonece to a ploneor Loulsyilo ramilg of Irlah stock.

EIIsha Davld Stanalford was born December 23, 1831, on Jefferson County farm within a few miles of the citg in which he spent most of his active life. Ie left school at the ace of slxteon, but was alroady a sood Latin and Prench scholar. Ho began his medical studies with "the well-known Dr. and prof. I. B. Plint"; he also heard lectures at the Kentucky school of lodiclne in Loulsville, from which he was pradiated. After several years of practice, he abanaoned the medical profession and cevoted hinself to acriculture and other enterprises --- for he was a bankar and raliroac prosident as well as a doctor and farmer.

He owned around 14,000 acres of 1 and in this section of Jefferson County, and, according to the Elstory quoted,

"The large acreage of land of which he became helr was kept in superb condition and was rade

1. Information on $7 \mathrm{r}$. Stanciford condensed from History of oblo palls citles and their counties. 
to yleld the largest crops with the least impoverlshment of the soll."

He ralsed extenslve crops of grain, and had a special foreman over each crop. He also had extenslve pasture land and ralsed great herds of deer as well as other animals. One pasture hac a fence twenty feet high, with barbed wire the top, to keep the deer in. The writer had the privllege of talking with the daughtor of a man who had formerly worked as a hay foreman for Doctor standiford, and she confirmed the historical account of his careful methods of farming.

The orlsinal standiford home, built by Blisha, father of Doctor standiford, was a two-story brick, but It has recently beon remodeled into a one-ploor cal1fornia ranch type howe. It stands on the preston street Fighway .

Sunmary of an Interview w1th the oldest ynown pe gident of the comraunity

As the lives of Jenken Phillips and Dr. Standiford span the time from the American Revolution to the latter part of the Mineteenth Century, the 11 fe of $\mathrm{Mr}$. Frank Yustes, who is still living, carries the history down to the present tino. Wuch of the information in this paper was obtained through an interviow wh wr. Frank Kustes, the oldest known resident of the community, who has lived to see flve generations of his $\mathrm{kin}$, and whose 
memory spans the whole tine from aarly forests to thlckly settlod streets. Kustes Avenue, near the Standiford Alrport, was named for an uncle of his.

Mr. Fustes, who now 11 ves at 645 Phlllips lane, was born on warch 11, 1070, In the same comunity in which he now resides. Is father bourht a laree tract of land from $\mathrm{M}$. J. Tare, wo omed a groat number of acres in the early history of the community. Mr. Kustes is still very active for a man of nearly four score years, and he is elfted with a very alert mind for a man of this age. At present, he operates a small garage, and he would feel very much depressed if anyone should intimate that he is too old to attend to a business without assistance.

Mr. Kustes has many recollections of the early days and loves to reminisce. But he does not live in the past. One of his fovorite hobbles is listenine to the radio, and he can chuckle with the rest of the merrymakers while the program is belng rendered. Mis daughter wh whom he Ilves, is of ten obliged to co in his room and turn off the radio lone ofter he has fallen asleop.

In talking with the writer, Mr. Kustes sald that when he was a boy most of the land near this community was In woods; that he had seen the trees assappear and the ground cleared of tumps and useless rubble; and that soon the rertile flelas bogan to abound in crops, 
especially corn. he has Iived to see quite an Iraprovement in the roads and highwags. At first the naxrow wagon rouds were very ruged, and at certaln times of the year were almost impassaje. These have been improved and now most of the roads have hard surface tops. 3r. Kustes has hauled many a wagonload of cinders from the Loulsville and Nashville Railroad yards at Floyd street to help fill up the deep altches and gullies that were plentiful in this commity. Oxen were used quite a blt in the development of this section of the country.

Mr. Kustes sald that during his oarly courting days he used to wear gumboots and ride muloback as far as Shlpp street, were there stosd a refom school on what is now Bellonap Campus of the Univergity of Loulsvilie. st shipp he would dismount and tie his mule to a post; take off his boots and leave then there; and put on the extra pair of shoos which he had brought alon. Then he would catch a streetcar drawn by mules and ride in to Loulsville to see his Elrl. Usually he would arrive In the city in time to seo the "old Lamplifhter" draw his small cart up near a ges post and light the ovening lamps.

According to ir. Kustes it is a far cry from the days (not so long aco in actual yoars) when cas lightod tho isreat white ways, when horsecars furnished the rapid transportation, when telephones (if any) had to be 
cranked by hand, and, beat of all, when courting was done on a horsehair sofa -.- but sometimes too well chagaroned. In those dajs there were wide open spaces, but, as he sali, nelghbors were nelfbors. The public ald not have to deal with such probloms then, as it does today. Fork and employmont could bo round by snyone wling to put his shoulder to the wheel. The community did not have to solve problems of recreation anc lelsure time, for whenever a little lelsure time was found, thero would be nelghborhood party such as a corn-husking or a quilt $2 \mathrm{ng}-$-bee.

"Yes", he relterated, "It is a far cry from my courting days to this speed-rnad world in which people today Ilve and move and have thelr wishes granted by merely pushing a button. People have gono long way since the year I was born, but wth all the changes that I have Itnessed. I feel that all is for the improvement of man'a progress."

Commun Ity Rosident tho Donated First school

Whon an Individual contributes toward the upbulld1ng of humenity and toward the educating of the youth in his community, the famlliar words of Tdw in liakham come to mind:

There is a desting that makes us brothers; wone goes his way alone. All that we send into the lives of others Comea back into our own. 
This quotation might woll bo applied to the person who, through her ow Eenerosity, untirine efforts, and sincare interest in youth, made possible the first school in this comunity --. Irs. Rector Johns.

\section{Johns School}

As already noted, it was not $t 111$ after orld far I that this area began to be thickly settlod. By 1925. the community, whlch was then known as the farmington Subdivision, was becoming more densely populated. The nearest county school was prestonla, about two mllos away which was too far for most of the children to attend, as there was no transportation furnished at that time, and they would have had to walk. Krs. Johns, who owned and rented about twenty-five houses in this viclnity, was very much interested in the school situation, and she sent her son to see the county super Intendent about furnlshlne achool for the children of this communlty. The following is an excerpt from one of the Minute books of the Jefferson County soard of Bacation: 1

Urs. Rector Johns of Highland Park proposes to furn $1 \mathrm{sh}$ a shool bulldine, 24 foet by 32 foet wth a 12 foot celling and properly 1ighted, to be erectod on the east side of the Ash pottom Road south of aastern parkay in the parmington subdivision at no cost to the Board, provlded

1. Jefferson county board of aducation, Loulsvilie, Kentucky. Minute Book 4. 1925. p 237. 
this Bosrd will supply a to zher and the necessary equipment for sald school.

The proposition as set forth above was accepted and the room was furnished as soon as it was completed. urs. John's son drew the plans for the bullding accordIng to the speciflcations furnished by the Jefferson County Board of Education; he hauled the naterial to the site; hired the carpenters, and put up the bullaine, at the family's own expense, at what is now 3923 crittenden Drlve (formerly Ash Sottom Road). The school was to be opened as soon as a toachor could be obtained. According to a statement by sirs. Johns, Mine days after my son saw the county Superintendent, school began in the little one-room school holise". This was near the beglnning of the school term of 1925-26, and about twenty-flve pupils entered the "Johns School" that fall.

The first toacher of Johns School, Marcaret thomas, is now Ilving in Phlladelphia, Pennsylvania, ane still corresponds wh thome of the citizens of this community. She was especially alarmed about them durine the flood of 1937, and offered her services.

Tribute to Mrs. Johns

This public-spirited cltizen is still living and still continues to taice an active interest in sill the affairs of the community. The Southern veokly, a community poper recently started to serve this section 
of Loulsville and Jefferson county, had hrs. Johst picture in one of Its early issues with story captioned, "yost Boloved Woman of Fighland Park."l Tho following is an excerpt from ir. Smith's article:

Urs. Johns was oducatod in the common schools of crajson county and attended a few of tre subscription schools or normal schools. Sho remembers well sone of the noral lessons in Zcouffey'g heacors and can yot recite many of the pooms.

In the sprine of 1905 , she and $\mathrm{Mr}$. Jokns moved to Mghland park, where they operated storos, lumber and coal businesses. "Aunt pina" took care of the office at the coal yard from 1910 to 1925 . She was nevor known to refuse credit to anjone.

Wany are the times that $M r$. and $\mathrm{Kr}$. John have Etven poor familles groceries and coal. The pastors of the churches in Highland Park always knew that these food people would help any destitute famils. Consequentig, it inleht be truthfully said that "Aunt PIna" and "Vncle Rec" operated a welfare store of their own, with no expense to the taxpayers.

1. Article writter by The Southern feokly, Lonisville, XY., Pebruary Id, 1949. Usec by permission. 


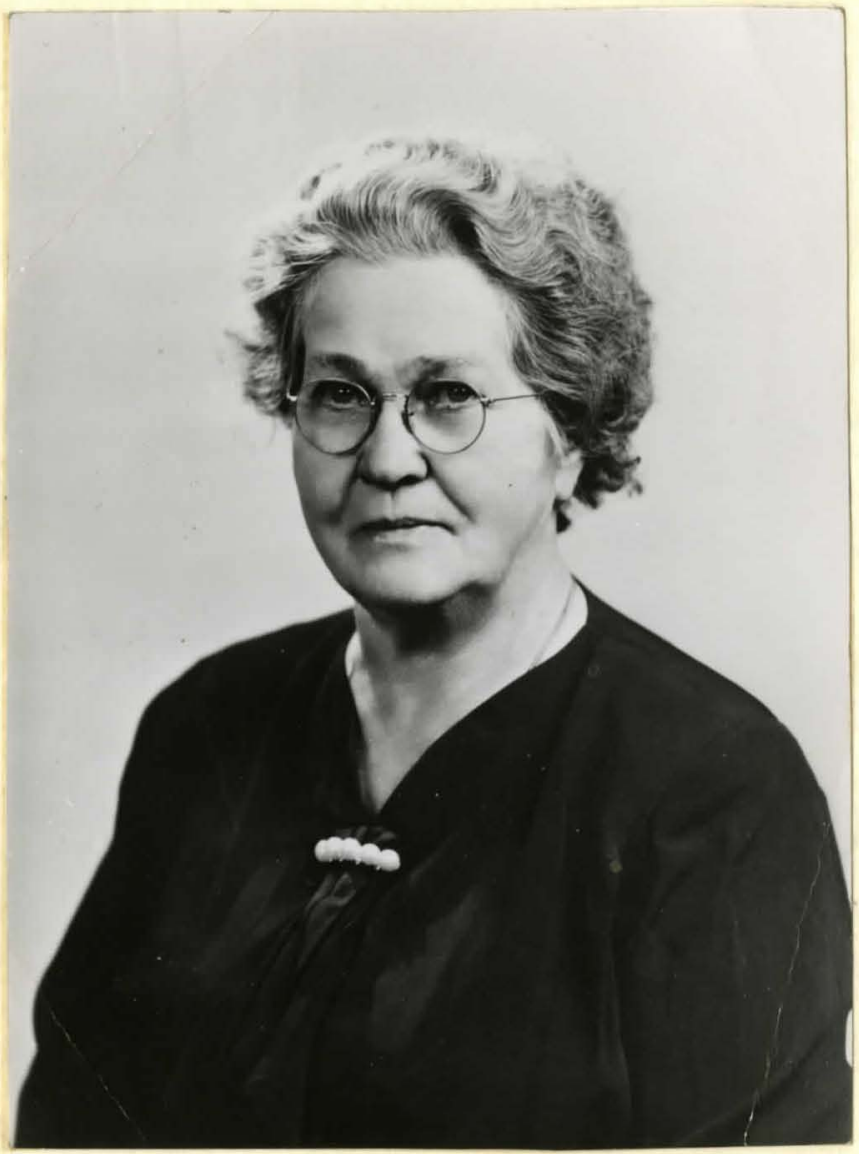

MRS. RECTOR JOHNS 
Iwo-Teacher school

For three school years, Johns school remeined a one teacher community school. Zut each year the community was growlne larger and larger in population and more placer of business were velng bullt. on account of this condition, the little one-room school could not accommodate the increasing number of puplis. At the beginning of the school jear 1928-1929, the same person again proved to be the "Good Samaritan" and again came to the rescue of the youth of her community.

Another room was provided, constructed according to the speciflcations of the Jefferson county Board of Education and another teacher was added. According to the agreoment, the Bome was to pay urs. Johns b40.00 monthiy rent for the extra room, whlle the first room was at 111 provlded at no cost to the Soard. For olght years. Irom 1928 to 1936 , this continued to bo a two teacher school.

Prestonla school No. 2

At the beginning of the school year 1930-1931, it was auggested by a ropresontative from the Prostonia School District that the Johns School be consldered a part of that district and that its name be changed to prostonia School No. 2. Thls suggestion was adopted.

Aeain the bullaing was beginning to be Inadequate to meet the neods of the frowing population. Not only 
was it too small, but it also needed repaifing. At one tine it was recorded in one of the linute books that the Preasurer of the soard a drected "not to pay any more rent unt 11 a hols in the floor was repalrod."l

\section{Adalr School}

In 1936 a lot was purchased from in. Ink for 425.00 for the purpose of erecting a four-room schoolhouse. This lot had a 100-foot frontage and was 200 feet deep. The plans for the bullding of this school were obtained from the state Department of aducation at Frankfort, Kentucky. Thus for the school year 19361937 a four-roon bullding was constructad on Adair Street on the east side of crittenden Drive, where the school st111 stancs. This school had a faculty of four, teachine Erades one through eight. This continued to be part of the Prestonia School District and was known as prestonla pistrict wo. 2, but the name of the school Itself was changed from Preatonla No. 2 to Adalr School, and it continues to bo called by that name at present. The estimated cost for the erecting of the four-room bu1ldine was $\$ 5,500.00$.

The new four-roon bullding still could not sufficiontly accomodate the number of pupl1a for very long and in 1938 a two-room portable was boukt from the Preatonia School and hauled to the Adair Jchool. 1. Jefferson County Board of Education, Loulsv1110.

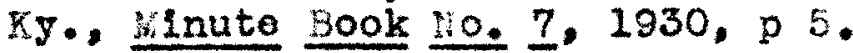


Ihis portable was purchased at an aproximate cost of 1,500.00. One room of this edifice was used as a classroom whlle the other was equipped with a plano to be used for a music room; each teacher was pernitted to co to the music room durine any music period that she desirod. Another teacher was adied, so that the school could now boast of a faculty of ine; this fact romalns true to the present time.

In January of 1941, the dair School Distrlet became separate from the prestonla District. It is now known as Adals District No. 78-2,

Early Examples of comunity-and-School Cooperation

For over twenty jears the school had no lunchroom. During a part of one of the early years, the prestonia P.T.A. cooked and sent over hot soup and sandwlches each day. Ihls was a nelghborly gesture, and was rendered wthout any charge. Later, Mr. and srs. Roy Collins, who operate a small erocery near the school, began to provide froe lunches with the cooperation of the wholesale firms with whom they dealt.

At that tine, the collins' own chlidren were not of school age, but they were deeply interested in the health and welfare of the chllaren in the comunity. since it was not possible to have a lunchroom at the school, these generous cltizens offered to make hot soup each day and to serve it free to each child. 
"Where there is a w111, there is way," and with the assistance of wline helpers, a way was soon found. The county provided most of the vegetables; bread was furnished by a Loulaville bakery, meat and soup bones by a wholesale packing company, and ples frequently donated by a ple company when they made deliveries to the collins store. Mr. and $M r s$. Collins would often stay up late at night preparing vegetables; if a neighbor would come over for short visit, this often afforded opportunity not only for frlendly soclal call but for additional hand to make light of preparing the vegetables for the next day.

Mrs. Collins ${ }^{2}$ cannot remember the exact year when this was begun; but she says that it was after the school had becons a two-teacher school, and while it was still called Johns School -- that is, some time between 1928 and 1930. She sald that they usually prepared lunch for about seventy-five people. This cenerous service continued for two years or more; but, of course, It was not possible to continue the free lunches inderinitely as the school continued to expand.

\section{Gift of Christmas Troes}

The evergreen troa has become probably the outstandine symbol of Christmas. There are many thrilling

1. All of the above information was obtalned through an Interview with hrs. Collins, who still operates a Erocery in the same community. 
experiences that the chlld may share at this season of the gear, In the home, in the achool and in the community. Christwas trees adorn not only many of the homes and schools but also places of business. A christmas tree not only enhances the beauty of the place where it stands, but it also suegots many upliftine thouchts and activitios of a constructive nature.

In the early years of the Johns school, during the terrible days of the "Depression", the flrst Christmas troe was given to this school. The donor gave it because she felt that the children of this community had so little when compared wth the chlldren of many other comunitios and she folt that this would glve them pleasure. This custom has boen extended through the succoodine joars.

The donor of these trees is ins. Suda . Butler, 1 one of the supervisors of the Jefferson county schools. About a weak or ten days before the christmas hollays each year, a truck drives up to Adair school boaring a large evergreen tree. This is placed in the first Grade room, and the chlldren from each room make decorations for 1t. The troe belongs to the school as a whole; and the working together of the children to make it attractive helps to develop a school spirit and a feeling of unity within the school. The man who 1. Mrs. Butler's name has been used by her peris 1 sion. 
now delivers the trees to the school is a son of the bus driver who dellvered the flrst two trees to Johns School. Mrs. Butler has said that she gave the flrst troe hop ing to elve tho chlldren pleasure and that she has continued to do so because $1 t \cdot G$ ives her plessure.

Award rrom county Eealth Department

Durine the early years of this school the city and County Health Departants were separato. It was the custon of the county Health iepartment to award a slver cup each year to the school that had mado the greatest progress in the improvement of the health situation in the community and also in beautifyint the surroundings of the school and in tho comunity. This cup was won by Prestonla school io. 2 in the school year 1930-1931 for havine shown the reateat improvement in health conations.

This Improvement was probably due to the direct contacts which the teachers made with the honos. It was the custom then for the teachers to visit each home, and many worthwile principles and suegestions for community Improvement were offered and put into practice in the comunity. Inls custom st111 continues in the present, and each teacher tries to visit the homes of all her pup11s each year. Wuch valuable Information is obtalned fron these contacts with the home, and this Information is used for the Improvement of both the 
school and the communty.

Response of Cormunity in fimes of Disaster

During the 1937 flood, the school bullaing was used as a rofugee station. There were only four rooms then, hoated by stoves, as thoy are tocay. over 200 refugees, men, women, and chilaren, were taken care of in the school. The fod cross fumished blankets but the supply was inadequato and the c:tizens of the comanity met the noed by supplying the rest from their om bomes. The chlldren were put to sloep on benches, deslis or floor.

The Red Cross also furnished some of the food for the refugees; but far bo it from anyone in that commulty to sit down to a hot meal or a table well laden wth food and not to share wh others in need. The poople of the community made sandwichos, salads and other foods which they took to the school and shared Wth the refugees. Whe teachers also worked out at the school together with the clitzens of the communlty In alding to meet the needs of the refugees.

wost of the land in this comnunity was drs, and the main inconvenlence that the people suffered was the lack of electrlc lights. Wost of the resicients at that the obtalned their water supply from wells which were not affected by the flood. One of the residents near the school had a doep well, about 70 feat deop. 
During the flood a representative from a hospital in Loulsville came out to her home and obtalned water to help supply the hospital for drinking purposes. At one the they took 30 cullons of water from this well.

These instances are characteristic os the people of this commity, for they aro always sympathetic toward any exergency and are ready to respond wholeheartodly to glve help.

Junlor Rad Cross hetivitios puring rorld war II

Each class was member of the Junlor Red Cross, but the puplis kept wanting a sponsor for the school as a whole and were anxious to do their part in helping wherever they could. So one teacher became sponsor, and an active Junfor Red cross was formed. Any pupil who desired might serve in the way in which he was best flted to contrlbute to the cause.

At each special season the club was asked to make a large number of favors for 11 chols Hosptal. The chllaren took dell kt in usine their own orielnality to decorate the different articlos -- favors, place cards, scrapbooks, momo pads, writing pads, etc.

an ureent call came for mufflers and sweaters. Whe children had never learned to knlt but wore anxlous to try. The writer, who was sponsor for the club, took It upor harself to teach as many as desired to leam 
how to knit. Twelve nufflers were knitted by ten nombers of the knitting roup, four of then by boys who learned during this time.

Twenty-five boxes were fllled by the puplis of this school and sent to childron in other lands. These boxes wero fllled with penclls, crayons, erasers, needles, pins, throad, handkorchlers, toothpaste, tooth brushes, books, writine paper, combs, washcloths and sone toys. Lare cartons were broucht oy the chlidren and the articles were placed in the boxes. Some of the older boys always carried the boxes to the carline, and if the box was very heavy he would accompany the sponsor to the led Cross Fealquarters on Third street. This was a wonderful experience for them and was thoroughy enjoyed by all. 
PART II 


\section{PARS II -- ADAIR NOW}

In this pert of the paper the writer describes the present school and its procram, and cont nues to show how the school and the commulty cooperate in working toward the good life for all.

Present 3chool plant and Personnel

As has been stated in part I, the school erew from the one room of 1925 to a four-room building plus a two-roon portable in 1936. Thls is still the size of the school plant but the increase in the number of pupils has been taken care of to sone extent tirough sending sone of the older grades to ther schools. In September, 1940, the seventh and eichth crados were sent to tho restonia tchool; and in september, 1949, the sixth orade is to be sent to the James inssell Lowell school on crittenden Drive and Phillips Lane, which is a part of the Loulsville public school system. Until the close of the school jear 1947-49, all eight prades were taught in the flve classrooms. (The portale has one classroon and its other room is the Iunchroom).

Each of the rooms of the school is heated by a coal stove and the end wall of each room is equipped with hooks for the cisidren's wraps. All the roons are supplied with electric lights and each one has an outlet for plugeing in for racio programs. The walls aro 
painted a 11 tht vided in oach room. Whe desks are of the old-fashloned uypo, with the iting gurface on top and books underneath. Crusked roct has been haulad and put on the playground to proves: unrecossary quantitios of mud and eirt from accumulating, in the schoolroomis.

here are five techers on the school stafi includlne the Principal, who hss a full teaching load. During the past gear each toachor had about thity-flve puplis; this was much lesis than the prevlous year before the seventh and elghth Erades ware transferred to prestonla. All of the flve toaberg have recolved their $\mathrm{h}$. 5 . degrees and four have had graduate work elsewhere in adation to the Univasity of Loulsville. me Trinclpal has almost completed tho requirements for a "totor's Degroe and the other four taachers are worklng toward that dogree at present. One momber of the faculty had completed a course in pre-nocical work before entering tho teaching flela. Sheir loneth of service at this achool ranges from three to twenty yoars.

Whe raculty members foel that the are fortunate in having as custodian or janitor a man wo not only takes pride and interest in trying to do his work well, but wo shows a deep interest and concern for the chlldren in the school. or example, on extromely cold momlne he entered a classroom and saw the toacher trying to holp warn the feot of a little chlld who had 
come to school with no socks on; from his own pocket he offered the teacher money to buy the child two pairs of socks. He is always roady to carry the pottod plants from the classrooms to his own home to protect them against freezing. If any teacher has a tas to be done, she merely leaves a note on her desiz and he tries to attend to it as soon as possible.

Not only is the custodian concerned with the physlcal welfare of the chlidren but he is interested in the ir learning as well. He often sits in the back of a classroom and listons intently to ang class activity, thoroughly absorbed in his intereat, not from his own standpoint alone but from the vlewpoint of what the children are learning. One day he brought his coffee m111, whlch has been in the family for over a hundred years, to the second erade roon and gave every child an opportunity to grind coffe just as their forefathers had once been oblized to do. The Loulsville coffee Company furnished the class with both parched and unparched coffoe for this experlence.

\section{The Lunchroom}

As has already been pointed out, there was no school lunchroom in the early days of the school. DurIng some school years, lunch was provlded froe by generous volunteers; during other jears, teachers and chllaren had to bring the ir own lunch or, if the Ilved 
near enough, go home for lunch. Nearly always those who brought their lunch also brought an oxtra sandwich for the "Euest table" for those who had nono.

The present lunchroom, which has been in operation for about three and a hali years, is an outrowth of the P.T.A., which was formally organizod in 1945. Some of the motherg felt that if a lunchroom were acied to the school plant it would contribute preatly to the bealth of the school and the community; and the untiringly towar conpliotine and equippins this. The county furniahed the stove, refrigerator, cabinets and plumbine fac111t10s; the mothers bought and made the curtalns, which they also launder, and they bought or donated cooking utens118, dishos and other necessary 1tems. Thus tho lunchroom as it exists today is even more an exmple of communty cooperation than were the oarlier froo lunches donatod by a small proup of people.

Three of the mothers are mployed in preparing the lunches, one as chalman or manager and the other two as her holpers. Nith the assistance of Federal ald an attractive and we11-balanced lunch is arred at a minlmum cost. If a parent feels that be is not financially able to pay oven this minimum cost, he has a conference wth the Principal and teacher; and if they foel that he is deserving, bis chlidren are furnished lunch without cost. The mothers in the lunchroom are also very cooperative with the teachers and pup11s. Sometimes a 
touber may feel that a child needs an extra sandwich or glass of milk during the morning; and it she sends him to the lunchroon he wil be served in a friendly and interestod way. These mothers slso often sugerst chilaren who need clothes giltable to the wastier.

During the past jear many of the parents in the nelghborhood were out of work for a period of time, as a result of strikes or other causes. vearly one fourth of the pupils have been on the free lunch list at some time during the yoar. In such a situstion as this, cenerosity mas perhaps be Imposed upon; but when so many cases are so urgently focused before one's vlew, It is cifficult to araw the Ine of demarcation. It is quite evident that a child who is malnourishec and lacking in the foods that are so essential in acculrIng and sustoining vigor and vitality is by no woans capable of competing with those who aro fortuncte enough to be well nour ished.

Parents' Cooperation with the School

As has fust been pointed out, the lunchroom was orlginated and largely carrled on by the parent Teacher Association. In earlier yoars the school had tried once to have B.T.A., but the parents at that time were slow in assuming responsibility. towever, when the new organization was formed in 1945, they took hold heartily and have done excellent work. Wo capaolo 
presidents hay helpel to guice the work of this sroup. During the first two yoars the mamborship incroased ten porcent each year; last jear when tho two upper grados were transferrod to prostonia, tho parents of those children naturally vocane numbers of the P. D. of that school. The Prestonia P.T.A. received the parents from Acials woleheartedy and gave them a leoling of wolcono and "belongingness".

In planning to establish the lunchroom, one of the first projects undertaken oy the amall and inoxporiencod P.T.A. was to procuro adequate financial funds. In order to do this, they staged rall pestival whlch provided many ways of macing money: a "fish pond" witich always makes people want to try thes 1 wcl. "just once more"; a "country store", of which all the stock was àonated; a popularity contest and alay; and nany handmade articles such as potholders, plllowcases, ombroldery and homemade cakes and candies. From thls one nliht's activity the P.T. A. cleared over 365.00 ; and the next year, at a similar affelr, they cleared $\$ 245.00$.

The P. A. A. has workoc bard at making monoy by a varlety of means. They must of nocessity use nethods requirine vory lialted amount of capital, and thoy have shown incenulty in doing this. They have had papor sales, and in each roon the chlld who brought the laresest amount of paper was iven a cortain amount of money as a prize. They have sola christnas carda and realized 
about 200.00 from this clone last pear. They sola school supplies in the lunchroom at the same prices for wich the articles could be bought at sny dine store; and from tha minor project they reallzed abont $\$ 70.00$ this past yoar. Kecentiy the P.T.A. Presicent esked that carton tops and wrappers from soap powcer, etc., be saved for the coming year.

$$
\text { The P.W. A. sponsored a supper under tho ausploes }
$$
of the knort Meat packing company, where all the foot was furnished by afferent conpanies advertising their products. Tickets weresold at a very nominal price and the mothers nace ples and salads as an addition. The manager of the Vifghand rark theater allows the nelebborhood schools (Adair, Lowell and St. Leo) certoin percent of the tickets sold for a show on a certain eate.

In order to function efficientiy, this organization must be very conservative in their actions. Eut the $z$ are ever ready to halp in ang way tow se furtherIne the interests of the school and the comaundty. The Iunchroon is only one of many contributions wich they have made. Other contributions are 11sted as follows:

1. Tach room has been equipped ith a rado.

2. A set of Compton's Iicture increlopedia has been bought for the school.

3. us trangportation for class excurstons has 
been pala by the P.T.A.

4. Bach chlld wo attended school without being absent a day during the entire jear was given a prize of 1.00 . (rwenty-nine received the dollar last year.)

5. Plrst ald equipment was bought.

6. Jach nonth tho room wich had the most mothers prosent for P.T.A. met Ing was Given a prize of 2.00 .

7. Bach teacher was ivon a cortain amount for library books or other equipment they might prefer to buy.

8. Other expensos were met, such as stato P.T.A. dues, Founders' Day contributions anci sinllar calls.

\section{Individual Contributions of parents}

In addition to the P.I.A., which inclucies all of the parents, each taacher has a "Roozi Wother" for her own class. The room mother is very helpful in alaing or outaining ald for the school health checkups. Sho usually accompanios tho class on any excursion and takes a personal interest in the chllaren"s welfare. In sevoral cases the from Hother has furn? shed refreshments for the room on certain occasions. Also, many notices which apply to all the parerts are diatributed throush the room mothers.

hile the mothers are tho official sponsors of the 
difforent rooms, the fathors also often wahe valuable contributions, sometires quite spontaneously and unexpoctediy. One fathor of a flrst erade chllc visited the room early one morning. ie alc not com prepared to make a talik to the puplis but to seok lnomation about a book for his aon. hinle ho was talking to the teacher in the front of the room. she mentloned the type of work ho solng, which was holping to mako glass. He made several intereating romarks about the common uses of glass, and sald that the tedious process of producling some forms of it just isn't approciated by most people. Then the notlced a broken glass brick which soneone had broucht and wheh was bolne used as an aquarIum for snalls and sunflat, and he oxplained to the class something of the processes by which this kind of brick is made and the ways in wich it is used. After he left, one of the chllaren remarked, "noll, he made a cood talk evan if he didn't mean to".

If It were posalble to take an intensive survey of the talent and valuable contributions that can bo found In a small communIty; one would probably be amazed at the remarkable ability that often lies dormant because the Individual has boon hesitant in offering his services. One father in this school frankly ackowledad that he probably would not be able to pass a test on second graco readidg level; but se is capable of readInc and interpretite blueprints of bulding designs. 
no has mace shelves are tablos for the school and has made radio cablnets for mang of the people in the community.

\section{Community Benefits from Cutside cooperation}

The preceding instances iven have shom how the parents have worled with the school to holp solve the probloms of school and comanity, workine rainly on the local lovel. Uven here, howover, there has been help from larger units, as in the lunchroom equlpment furnished by the counts Board of rducation and the financlal assistance elven by the rederal hid program. where are some problems that cannot be entirely solved b. the people of the small comunity themselves, and here outside agencies come in to Give ald. Among these problens is that of providing adoquate and wholosone recreational facllitios as one way of helplag to prevent juvenilo delingueneg.

there are many boys and girls of high school age out of school but w thout work. wany of them are on the road, and the problems with which teachers and parents are confronted is how to remedy this situation so that the future may offer a brighter outlook for the youth of today. Llfe can be just as dull and drab, just as uninterestin; and emptz, in rural or small communtios as in the back alleys of bis clties, and it is very important to provice op portuntites for wholesome 
recreation for such young people.

There are two agencles in the Highland Park area, near to the Adalr school, which are orking to meet this problem, both of then inltiated and financec from outside the local communty and both contributing preatly to the happiness and wholesome $11 \mathrm{v}$ ing of the children and youne people of this area. One of these is the 1Ehland park playground of about twenty-two acres. This playground, which has been in operation since about 1929, is under the diraction of the Recreational ivision of the city of Loulsille and has an efficlent Instructor in charge at all times. Classes are held in creativo arts and dramatica and a stace of fers an excellent situation for presenting plays and skits. During the summer most of the activities are carrled on out in the open; in winter the recreation rooms are used.

The other recreational acency whlch is of great beneflt to the community is the optimist Boys' club, located near Furon and Park Boulevard, which was bullt In 1946 by the Loul sville optimist Club of businessmen. The Optimist Boys' Club has a membership of about 250 , ranging in age from seven to seventeen. All of them are from the Highland park nelehborhood except two or three from the Beechmont area; and many of the chlldren from Adair school are members of this club.

This club boasts one of the largest librarles for boys in the South. At present there are between 500 and 
600 volumes of worth-while 11terature for boys. Opportunities are also offered for boys to learn some of the fundamentals in block printing, woodwork, clag modeling, and sports of many kinda; and there is a photographlc laboratory, under the supervision of a young man who is attending the university of Loulsville, where the art of developing pictures may be learned. A free plcture show is presented every Friday nlcht for menbers and their familios.

This club also sponsors a trum and Bugle Corps, and this spring the members of this corps were furnished a day of wholesome and valuale entertainment. hey had lunch at the Seolbach Fotel as the guestg of the Loulsville optimlat Club, and after lunch were guests at a ball game at Parkway lold. Thls was the pirst experlence that most of the boys had ever had in eating at a hotel, and one that w11l never be forgotten.

The effect of these two recreational agencies on the life of the communtty has been very arked. The manager of the club recently made the statement that since these two gencies have been in operation, juvenlle delinquency in this area has decreased around slxty-five percent. This is surely a good return on the money and offort invosted in such causes, and should be most eratifgine to those who have made these possible, as well a to the people of the communtty who benefit from the club and the playground. Both the parents 
and the children are most approclative of these recreational opportunitios and the local comunity people cooperate in every way possible with the club and playEround alrectors.

The Sctiool Frainine chllaren to be Good citizens of the Community

Many of the Instances of cooperation given on the preceding pages have shown what the community has contributed to the school. In the following pages the writer will describe some of the ways in which the school seoks to train the chlidren to be good cltizens of the comunity. Since the writer teaches the second crade, many of her examples come from that grade; but examples are also included from other erades and from the program of the school as a whole.

Training in Fealth and Nutrition

For the past two years a preschool clinle has been held each spring. The mothers brine the children who are to enter school the next fall. Bach child is examined, in the presence of the nother, for any physical defects and for lmanization. The preschool children are invited to attend school for few days as class visitors in order to help them become acquainted with school 1 ife and to becore more easily adjusted in the fall.

Typhold shots are given each spring by the Health 
Departmont and ech teacher endearors to Impross upon the children the Importance of being able to prevent opldemlcs by Imunization. Sone of the rooms were nearly one hunared percent in taking the typhold shots this year. Many of the wothers of the comunity also come and bring theis zounger children to take the preventive shots against typhoid, and some have taken the shots thenselves.

Nutrition education is a definite part of the program. Part of this is curriod on through the Iunchroom; but the teschers take every opportunity to work this in also 28 a part of their classroom activities. The chllaren of the flrst arade had the pleasure of propange a large indow box for tho purpose of planting recotablos. The planted lettuce and some othors. Just about two weoks before school was out they had the rare privilege of eating lettuce from the ir own garden that they had tended so carefully. The lettuce was preparoc in the lunchroom and served to the flrst grade as an addition to thoir regular lunch.

Along with nutilition education, the lunchroom also provlas opportunlties for tralning in taklo manners and soclal graces. It has beon found helpful to have a host sud hostess at each table. The chilren are pornitted to talk durlne the lunch porlod in a gust, conversational tone; and they help to select whlch toplcs would be more deslrable tian others to dsscuss durlng weal 
times. This perlod presents naturel, social atiosphere, and such tale conversation is helpful in preparine the child for social contacts in later 12 fe.

\section{Irainlas in sufetr}

About ono-third of all fatal accldents occur in the home and if this groat peril is to be dininishec, parents, teachera, and the whole community must work toward that 6ol. Also, it is no unusual thing to read in the dallg papers that a small chlld has been struck and perhapa fatally injured on the highway. Since all the children who attend this school must rels on the is own judgment, or that of an older relative, as to when to cross atroets oach toacher tries to instill into the chlldron the need of practioine safoty in coine and comin fron school, as well as on the plageround and in the rose.

Wang of the youncer chllaren could not uncerstand the reasons for the instruction that the should walk on the left side of the hlyhay, whereas when walking on the sicowalk they should keap to the right. 0 make this clear to the chilcren, the teacher of the second Grade took her chliren for a ralk of the highray one aftornoon, so that they aight understand the reasons for facine traffic as they walked. Thile they were returnine from this walk, an unexpected observed approached and asked to take a plcture of the class. This contlomen proved to be lajor I. L. smith, who has alroady been mentioned in this paper as Asalutant zaltor of The 
Southern weokly.

One day early in the spring. Immediately after the lunch perlod, the chlidren wero very much exclted when they saw a fire engline stop right near the school grounds with two police cars closels following. It was soon discovered that a fleld gust across the road from the school was on fire and that some of the houses vere beling threatened. After the chilaren oame into the room, they could st111 see the fire and the efforts to extingus sh 1t; and this naturally ied to discussion of the incident. Mang suppositions were expressed as to bow the flre could have started and many useful suggestions offered on how to prevent such dostructive disasters. The chlidren could as lly seo how carelessness in regard to fires can lead to loss of property, time and expense and even to loss of I1fe; anc they ware adopt in enumerating the preventive measures that one should be dally consclous of in orcer to prevent the destruction.

\section{Train ing in Conservation}

Much has been sald about the urgent need for conservation of netural resources. But how can a chlld practice the art of conservation if he has not been taught it in the home and school? This can readily be correlated with other subjects in the school curriculum. The chlld can underatand that conservation by ind Ividuals leads to conservation by larger units of community, stato 
and nation.

In this school it is not an uncommon sicht to seo pins of valous kinds roplacin buttons or snaps on dresses or shirts. In a health check-up one morning the teacher was atruck with the number of missing buttons. If buttons had been on the scarce 11st, on an expensive Item, sho night have shruged her shouldars and passed the inclinet oy, deciaine that if the pin served its purpose nothing else mattered. But since buttons are plentiful and cheap, she declded to initiate a button project. She pointed out to the class that it would seem very much out of place if a nall wore used where a button should be; and she talked of the ways buttons are made and the functions they serve. The chlldren were Interested, and could easily realize the harmful effect on their garments when buttons were replaced by pins.

After welghing the matter very carefully, these second srade chlldren declded to have a sewlng klt in the room, to be equipped with spools of thread, buttons of assorted gizes and colors, thimbles and neodies. Yost of these articles wero brought from home and it was decided that no one who had lost a button of ang wearIng apparel was to $\mathrm{g}^{\circ}$ home without sewing on a new one. As a result of this project, most of the chilaren in this roon could not only sew on buttons very neatly, but could often be seen mendire a rip in their clothes. This sewing kit was not for the use of the socond rrade 
alone; any chlld in school was free to come in and use 1t. It was not an unusual sight to seo a boy sewine on a button, mending a rip caused by play, or helping another boy mend his clothes.

One saall clul, who was not able to compote with her clasmates in academic work, proved to be the little seamstress of the class. She not only learned to sew on buttons and to mend torn places, but she recame the envy of the class wen it came to blind stitching. She learned to do this very nicely for a child; she wants to be a soamstress when she grows up. Her parents are separated, and it is perhaps through nocessity that she seemed more domestically inclined than the averace child for she showed slgns of having had experience in helping to plan and care for her own clothes.

Two of the irls in the upper grades had quite a responsiblilty at home, for their mother was in tuberculosis sanltorlum. These girls of ten had dresses given to them that noeded monding or neoded to have the hems let out or taken up. One of these girls renarked that she didn't know how to do this, but that perhaps her mother would be able, to do it the next tine she went to soe her. She was made to feel froe to use the sewing Kit and was given some simple instructions in sewing; and the writer feels that she will become more interested in taking care of her personal belongings as she learno some of the fundamentals of such care. 
This was felt to have been a very valuable experlence for the chlldren. Each chlld took a greater pride not only in his own porsonal appearance but in that of his assoclates, and from the favorable coments made by the parents it seems that this pride has been carrled over Into the homes.

Training in Social situations

Chlldren are usually thrilled with the ldea of a party and the thrill is even greater when they themselves have a large part in planning 1t. Ihis was the case with the Second Grade Valentine Party on Eebruary 11, 1949. For many of them it was the first experience in helplng to plan a party and make it roally thelr own. They worked in different groups in preparing for this party. and the preparations and plannine were a chlef toplo of Interest for sevoral alas before the actual party.

The group assigned to decide on table decorations had quite an experlence in looklng at plctures of different kinds of table settines. At last they declded on an Idea; and each child was asked to bring all the small ploces of rod candies that he could flnd. These were melted and poured into a small jello molc. After the contents had cooled, it was removed from the mold and placed in low, shallow, sparkl lne glass bowl, where it floated on the surface of the water; and three small magnolia leaves were washed and waxed and placed In the bowl. Thus a beatiful centerplece was formed 
whlch rogembled water $111 y$.

Another comittee preparad the reading tablo for the party by corering it with white crope paper and cutting a large red hoart for tho center and four amaller hearts which were pasted on the corners. The bowl was placed in the midele of the large center heart and the chlleren Ereatly adired the ir hand'work. one $11 t$ te eirl sald, "That is the prettlest table I ever saw and I'm golng to flx our taole just 11ke it the sundag".

In discussing hat refreshments to have, it was discovered that many of the chlldren had never drunk hot chocolato; so it was decided that tho class would help to prepare this drink. Mach chlld neasured out so much sugar and then so ruch cocoa; this was then taken to the lunchroon, where the milk wes added and the regt of the process was einlahed. One of the lunchroom ladies brought the steaming chocolate over to the classroom and It was served in indivldual paper cups with home-made cookles which had beon donated by a person very much interested in the pup11s. The toacher afterward found out that sevoral of the pupils had carried ints the ir homes the ldeas of both the decorations and the hot chocolate.

on valentine Day it is the custom for the children to exchange valentines and also to invite a visitor. mis goar their guest was a little boy, Larry vays, who had just returned home from the Kosalr Crippled Chlldron's Pospital where he had been confined for treatment 
for several months. This was to be his first visit at school since his return home and the first tine that he had ventured out with his new crutches. Tho puplls declded that the would all give a sall amount of money to buy hin a cift anc the one who was asked to buy the present selected a small red heart-shaped box of candy. Before Larry's arrival, the children talked over among themselves fust how the should recelve him and make him foel comfortable and at home. Larry is to be a member of the first grade this coming fall and the children are deoply interested in his welfare. Joth hosts and guests thoroughly enfoyed his visit at the parts.

Training in observation and Appreclation of Nature

Probably there was no more interesting part of the secund grade room than the "Sclence corner." Chllaren are usualiy intersated in science bocause it gives them an opportunity to observe plants, animels and nature, and to learn something concernine them. Wang interesting specimens have been brought into the school room, not only by the children of the second grade but by those from other grades also. Whese specimens have been observed and studiod not by the children of this one room only; for any child from the entise school was made welcome to visit the "sclence comes" and to use the reading glass in order that the subjects could be more closely stuciea. some of the interesting things brought for this corner were; ants, a enake, a sala- 
mander, frogs, tacpoles, earthworms, snalls, leoches, moths and fish.

Last fall at the becinnin of school, aevaral of the chllaren brought in cocoons that they had foxnd. These were kept in lars and in orcer to keep then supplied vin molsture the chlldron sprinkled them with water once a weok. In Asin thlo, thes lesmed to hande them vory carefully; and they looked forward ederly to the time when the noths would emerge. One day iry ar. just after the class had come into thoir room from the ir lunch period, that Iong-awalted experience was taking plaoe. In order that all might view this 3 get, the jar was placed on the teacher's deals in the frort of the room. Pregently they saw a beautiful cecropia woth orawl forth from its queer winter crade anc slowly begin to dry its wings by eraduall moving them back and forth.

some of the cillicen Immediately began searching the different aclence books on the sholf for sone deflnite information concernine this moth, while others looked through the sclence scrapiook which had been made by the class in order to soe if they could Iind a specimen like it. To their ereat deIisht, they found a colored picture whlch had been obtalned from the agazlne section of the Courlor-Journal and had been made by the photographer, Farold Davis. This too was a Cecropla. Who chilaren always get much joy out of sharine the ir experiences wlth the other teachers and chllaren; so they carried the moth 
to the other rooms and told its story.

Having found out that moths $P 1 \mathrm{y}$ by niEht, one child sugeested that this noth be placed in a cage and allowed to hand out durin the night, lth the hope that another moth of the opposite sex micht find it. Mhis was done, and to the great delicht of the children arothar moth was found near the cace one norning; tut as the foolers of the two were of practically the same lonth, they felt sure it was of the sane sex. This took place almost at the last of the school term.

The chlldren asked one day that they might be allowed to bring their pets to school and tell about them. on "Pot Day", the followlne animals were brousht from the homes: a whte rabbit, a gulnea pis, white mice and a pigeon. Bach child was permittod to 0 to the other rooms at a convenient time, as previously arranged wth the teacher, and tell about the care of bis pet and anythine of interest that ho wanted to add.

\section{Training in Appreclation of Their own state}

When school began last fall, an opportunlty was Elven for each child in the second grade to tell how he had spent his vacation. veng of them had stayed rather close to the home communty but some had visited several places of interest in their own state and had brought back pictures and souvenirs to show to the class; very few had cone outside the state. The reports of pleces 
visited began to arouse a deoper interest in the places in Kentucky that would be of special interest to sightseers; and It was sugEested by one of the puplls that the class make a scrapbook of such places. The book was made of extra largo drawing paper, with the cut-out letters $K E N T O C K Y$ pasted on the front; in the book the chlldren pasted post cards of different kentucky scenes, magazine pictures and articlos of special Interest about kentucky. This caused the chlldren to be on the alert for pictures suitable for the book and it was also beglnning to acquaint thom with nowspapers. They intend to continue this project during the coming school year. Puplls from other grades often contribute interesting pictures and articles for the book.

Children are alwags interested in visiting parks, and they had many park plctures in their book. One of the boys had vislted Columbus Eelmont State park at Columbus, Kentuckg. He was very much interested in the buge chain that had been usod across the ussissippl River durine the C1vil War as a blockade to keep the Incoln Gun soats from passing down the river, and also fascinated by the large anchor that had boon used to faster the chain. On the trip someone had related an incldent that happened only a few years ago when a large section of land heaved slowly into the river while some chllaren were attending a church picnlc at the park, and some of the chlliren started to run away be- 
cause they thought the crack in the oarth was a huge snake. This proved to be an excollent oxample of soll orosion and one that they could easily comprehend.

These second rade children were especlally interested in mamoth cave hational park because several of them had visited this park with thelr families. They found this very interesting and felt that they had somethine in common with the seventh and olihth crades, who had visited the park in the spring of 1948 as a school excursion. The chllaren wore ospecially interested in the underground dinlne room, Echo flver and the blind Ish.

Many boautiful scenos of "iny Old Kentucky llome" were collocted and pasted in the scrapbook. Mhis was very helpful in teaching music because many of the songs about Southern customs are sald to have been written by Stephen Collins Foster while visiting there. The Gachary Taylor Monument was interesting because he as the only presldent ho was lald to rest in Kentucky. gome of the children often went to corbin, Kantucky to visit relatives ana they contributed quite a number of plctures of this section of the state. They connected scenes of the Wilderness Prall with the storles they knew of Janlel Boone and pletures of Cumborland $\$$ with a story about colonial times. 
place at Hodgenville. Durlng the month of Vebrury they were ospecially interested in collecting material on Lincoln.

Introducing children to lational Interests

The Kentucky scrapbook lod the se second arade chllaren beyond the limits of their own state and gave them their first introcuction to people of national interest. I'hey had adcod to their scrapbook many pictures of botk Presicient pruman and vice-president Barkley and this made them very much interested in listening to the Inauguration program. After Iistening to this, some of the class suggested that they write a letter to vicepresldent Barkley congratulatine him and telling him that the class as a whole was proud to have a KentuckIan as one of the outstandine leaders of the nation; also that they would appreclate a letter from him to place in their Rentucky 5ook. A vote was taken by the class and all agreed that it would be a splendld ldea to write $h i m$.

The writing of the letter was a good example of cooperative group thinking and democratic action. The room chalrman presided while the teacher rules lines on the blackbourd wth a jordstick and chalk. The wording was to be the children's own product, and if in any case they could not agree on the wording, then a vote was to be taken and the majority vots would rule. There was much excitement ss some expressed themselves: "Do you 
think he w111 answer?" "Hy, I never thought that I would be writing to the V1ce-president."

Whe letter was progressing very nicely unt11 the word "lonorable" was usen. Other titles wore sucgested but to no avall. one littlo eirl in the class, who was a cood 1 latener and always very alert sald that sho had hoard them call him "The Fonorable Alben " Farkley" over the radio and that that was what they should write in their lettor. It certainly was a fascinating oxperience to hear thelr discussions on the pros and cons of this 1asue. They flualig compronised by leaving off "rhe" and addressine him just as "Fonorable Alben Barkley." Some of the members of the class were st111 not in accord with this formal title and one of the boys renarled: "we11, I st111 don't 1 lke the word lonorablo. It might sound all right whon the gas it over the radio but lt st11I just coosn't sound l1ke us."

The chlldren's letter to vice-President arkley has been photostated and may be noted on the following page. A copy also occupies a coveted place in the Kentucky Book and another copy in the book in which the clas a complled all the letters which they had written or recelved durline the joar.

within $20 s 3$ than a wook, a roply arrived in an officlal envelope with the V1ce-prealdent's facsimile signature on the outside. The reader can easily Imagine 
64

$5+8$ E. Adars St, at foursville, Ky Hon. Alien W Bark it Big Washington M.C Barkley, We listened to the in augural program over our radio at School. We are so happy and proud to have you for our Vice president and especially as you are f rom Kentucky.

Our legend grade at School is making a book about kent caky. We know that you gre Very busy. but We would appreciate it
Very much if you would find time to write us a letter to put in our

and Success. We will always be happiness interested in you.

Your friends,

at A dar School 
the thrill that tils gave the chilaren. The teacher called the room chairman to the front to read the letter to tre class, holplng hor with the diflcult words. Then aifferent members of the class took the letter around to each of the other rooms in turn anc reac it to the other classes. on returnind, each messenger prowely roported, "I knew all the words except - and the other teachor helped me with thoso." to Princlpal was just es thrilled as the chllaren and enjoyed teasine them about their offlclal correspondence.

Since some of the children had brought a newspaper pleture of Prosident rruman bolng entertained with sane of his Kentucky relatives, the class thought that a letter should bo written to him also. phe letter to the Prosident was written by the same procedure as that to the vice-presicent. The class also recelved an answer to this letter, but were a 11ttle "Iet down" because it was written by the president's secretary instead of by him personal15. This gave an excellent opportunity to show the great respons1b111ties that one must carry when holding an important office; and it was explained that it is necessary for such an offlclal to have secretarles to help bim in his work.

She letterg to the prosident and V1ce-president, and the answers recolvod, made the children alert to notice further pletures and headines in the papers. The Apr 11 issue of the magazire published by the National 
66

OFFICE OF THE VICE PRESIDENT WASHINGTON

February 5,1949

Members, Second Grade

- dais school.

548 East Adair Street

Louisville, Ken tueiky

My dear Friends:

Your letter of January 31 congratulating me upon my election and inauguration as Vice President of the United States has been raceived and read with much interest and appreciation.

I am very grateful to you for your generous expression of good will and friendship and I certainly appreciate your thought foulness in writing to me.

My I express to the entire class my interest and best wishes now and for the future, as well as the hope that I may have the opporrunty to meet the entire class in person at some convenient time.

Please express to each member of the class my personal appreciation for the letter which

$i$ I have received.

With every good wish, I, am

$A T B: b$

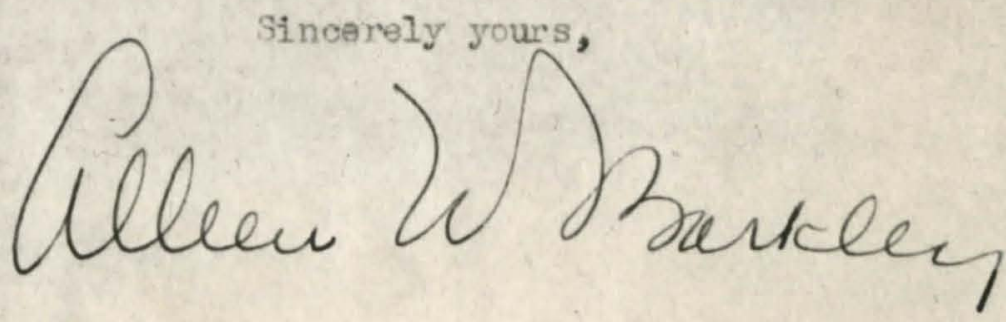


Soclety for orippled Children and Adults carried an articlo and pleture which were of doublo interast to the chllaren because of their personal contacts. This showed Vlco-presldent Barkley buylne the first aster seals in the 1949 campalgn; and one of the two 11 ttle boys shown with him was Larry mays, who had been the ir guest at the valentine party. (Picture on page 08.) Larry has shown moch progress since taking treatments at the Kosair Fospital and overy child in the community is really pulling for him, as well as the adults. Larry's mother and aunt have beon act Ive members in the P.T.A.

Develop1ne spreciation for other states and countriea

Children should be taught to recognlze the abli1ty and cood quallties in other people as well as to develop these in themselves; and they should learn to appreclate other states and other countries as well as to have a pride in their own. Profudice is sald to be acquired rather than inherent; and this is an encouraging thought for what has boen learned can be unleamed and with the sincere and whole-hearted participation of toachers much can be dono toward increasing approclation for other people and other nationalities.

In addition to their scrapbook on Kentucky, the children of the second grade have had quite a number of axisita from other states. A cotton plant was broucht back from Nabsma by one of the puplis who had 


\section{Easter Seal Bulletin}

The NATIONAL. SOCIETY for

CIIPPLED CHILDREN and Adults, Inc.

\section{S. LaSalle St., Chicago 3, Ill.}

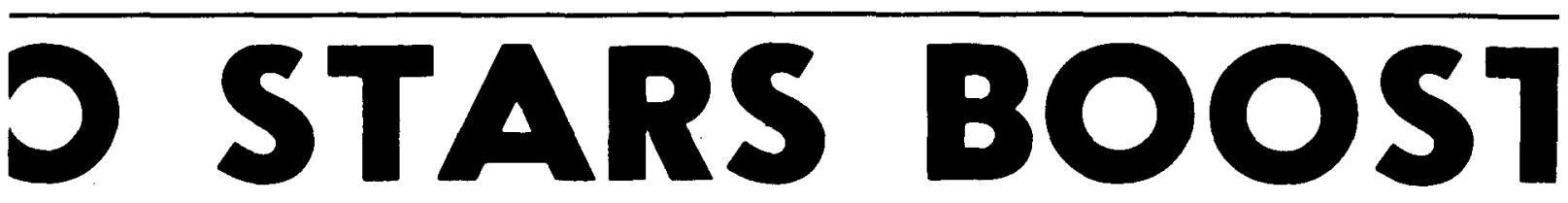

\section{Vice President Buys First Seals}

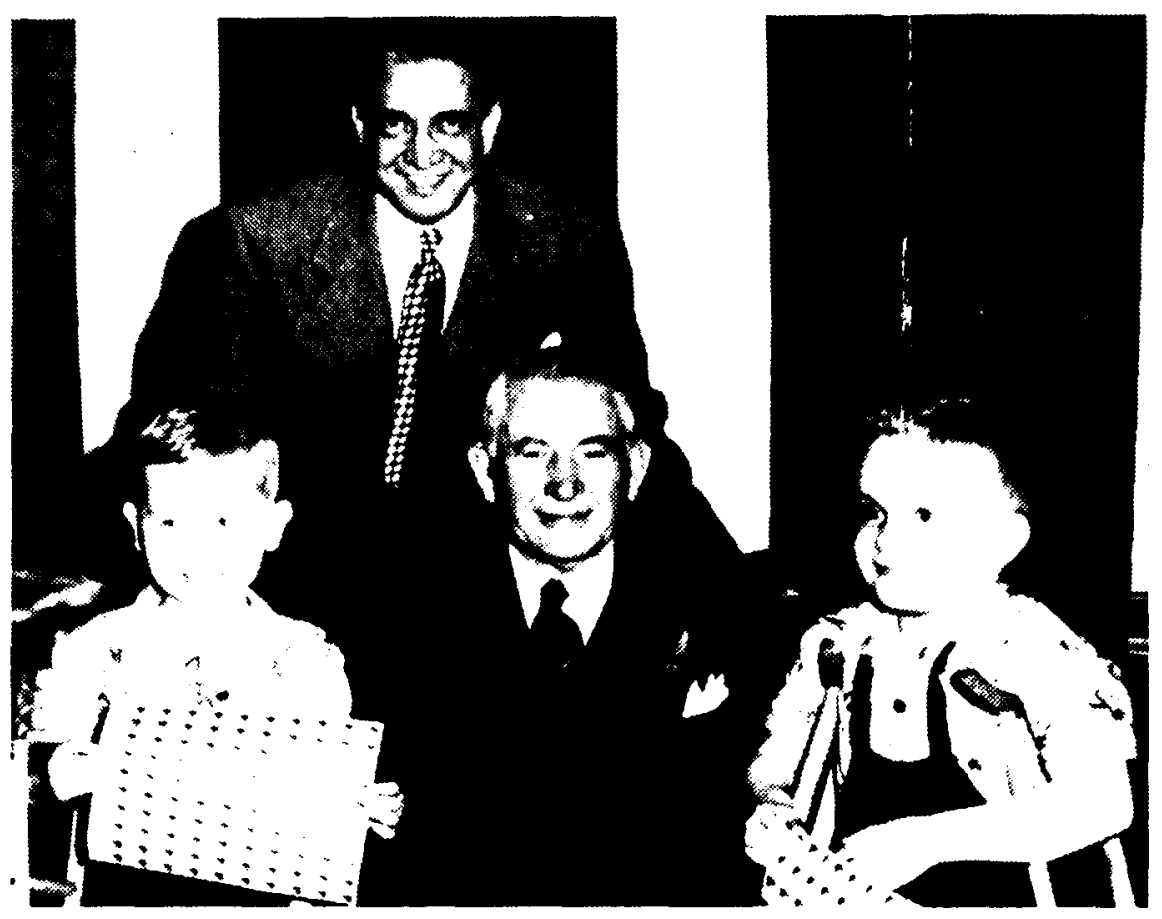

VICE PRESIDENT of the United States Alben W. Barkley officially launches the national 1949 Easter Seal Campaign. Presenting the Vice President with seals in Louisville are Larry Mays, 6 (left). and Eugene McAlister. 5, both of whom are being assisted by Easter Seal services. Sidney Rosenblum. chairman of the Kentucky Easter Seal Sale, looks on.

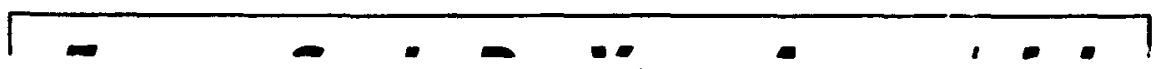

\section{Nationwi Start Off}

National publicity to a flying start duri: siars on all network: nesisatge to millions c

Additional commit: went to pressis. and it are giving a boost to shows have been line Art Linkletter will for the Nebraska Sox at $10: 30$ 1.m., W.ST, ]

\section{Linkletter :}

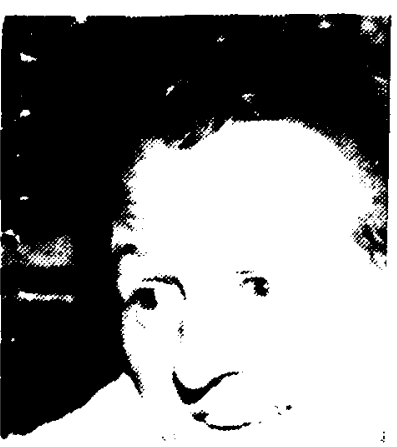


Visited his crandparents there; and cocosnut and 2 palm leaf were brought back by some of the pup1ls who visit Florla each year. These were shellacked in order that they might retain their natural color as long as possible.

Shells and sand from alkikl Beach ware contributed by some friends who were at pearl furbor at the time of the attack on Decomber 7,1941 ; and small replica of a Japanese fishine smack was presented to the class by some friends who had traveled rather extensively and wanted to add something to the collection of souvenirs. This shows the type of boat which the Japanese use for doop-sea flshing.

The children had been studying ant on Indians and had made mural depleting early ploneer life with the red race. Whis unit was mentioned in the presenco of young chaplatr and his wife who had been stationed at seattle, ashington. One day, to the surprise of the class, a neatly wrapped package arrived for tho class from these frlends. When opened, it proved to be replica of one of the largest tatem poles used by the Indians in Alaska.

The most impressive exhiblt from foreign lands was a loan exhiblt in one of the other rooms this spring. cne of the fathers has had quite a wide experience, havIng veen stationed in hasks, in the kloutans, in south imerica and present, in Japan. This father 
serds qulte a number of interesting and unlque ficts to ing ramily and they are always nost anxlous to share their privileges weth the puplls and teachers in the school. This exlublt consisted of dolls representing the Japanese Imperial Fandly. They were carved by hand out of wood, in the most delicate and intricate fasilion, and dressecin imporial robes such as one sees pictured in the pre-war Iiterature about that nation. They were examples of the kind of ant usually seen only in museums; and it was a rare prlvilege for all of the nenbers of the school to be able to see and appreclate these.

\section{Developing Apprectation by School Excursions}

Wany of the examples elven above have shown how appreclation has beon developed through pictures, exhiblts, or reports of a few individuals. In adaltion to such vicarlous experiences, the school has also sought to expand the puplis' horizons as much as possible by alrect personal experience. There heve been a number of excursions by different grades to points of interest in the surrounding area.

Among these excursions, two were for the purpose of helplng the chilcren to know and apreclate the sources and processes represented in the milk they drink. aghty-seven puplis of the first, second, third and fourth grades, accompanied br three teachers and $s i x$ 
rothars, visited the sesitest vary on oak street. por most or the pupils, this was thoir clrst visit to a dafy. They were interested in seelne how the milk was recelved and handed at the dalry. The crowd was d:vided into three groups for the trip throug the dary, In ordor to recelve the greatest beneit from the cuides. Tho older chlldren were espectally fasclnated by the buge anount of cottae che se that was being made; and all wero cellghtod when they were served wh th lce cream.

The second dairy trip was to Plalnviow Fams where the children had charce, many of them sor the first tine, to see cows milked. The culde who directod the croup through this dairy was a former pupil of the Adalr school and was very much interested in the children. Phey had a chance to see the large male cows, the mllch cows and the baby calves. One of the employees was very jolly and friendly character. He saw that each chila had a chance to pet a joune calf, and also to see how the electric milker worked. Here, too, the chlldren were served -- whth plain milk or chocolate milk as preferred. Through these dairy trips the chlldren were more doeply inpressed with the need of coperatine with others for food and santation.

Only a very few of the Plrst and second grade children had ever ridden on a train. So they were taken to Louls ville by bus; each child brought his own eleven 
cents and was responslble for buylne his own ticket from the Daxter Avenue Ctation to the onion station. Sixty chllaren, two teachers and five mothers went on this trlp. The group occupled two coaches and the chiliren were permitted to as? the gulde any questions the they desired. They woro shown throuh the aning car and Kltchen and how the bods were made in the pullwar car. 4 movle was show to the group after they frrived at the union stetion. This was an expenlence for all, for It was the first ine that any of the crowd had ever been invited to visit a train kitchen and see the cooks busy preparing the meals. ilth so amall a space to work in, they seemed very efficlent.

The teachers declded that it would be a nice experlence for the sane children if thes could take a trip across the onso niver and into mother state; and this met with the whole-hearted approval of all. Transportation was provided by chartered bus, pald for by the P.T.A. They went across the vuniclpal prlage to Jeffersonville and returned throuch New Albany and the K. and I. Bridge. Nang of the chlldren had never crossed the river before. This trip gave them an opportunity to see the ohio sith the many small boats on Its surface, and they also had a vlew of the locks. After their return, when evaluatine their trips, they declded this was one of their best.

The fourth and ifth grades visited the courier- 
Journal Dullding st sxth and roadwy. ho of the ir first experiences was to operate a solf-service elevator to the fourth floor. This was very fascinatine to them. hoy vistud tho Inotypo room and saw how the type was set up and how a pase was assombled. Thej saw the one belng assembled that would apear as the homan's pago of the Lousv111e was for the following rondat aftornoon: and they woro mch plossed when they sav the sane pace in print and could toll the other childrer about 1t. The Imanse blobo in the entrance to the buliding was interasting to all; and so were tho lareo printing machines. They saw how the macazine section was printed in color and laarned that colored magazlno soctions for the nowpapere of other citios aro also printed in this bu11d InE.

These same rases also visted the chliron's department of the public Ibrars at nhind and York. They onjoyed lookine at the books and mateanes, I1stenlne to the records and looking at pictures throvin the stereoscupe. Elims on rex:co. rast, but greatly engyez, was the Natural ristory vuseum in tho basement of the 12 brary. Ith ita mang interesting exh1bita. The mung and huge sheletor of a whale, as well as the stured blras and other 1tens, held a woalth of interest and conulne valve for the chiloren.

After visitine the library, the croup stopped at 
Contral Park and ate the lunches whlch they had brought with them. There they spent one hour fust playing and roaming around at w111. This was the first visit to this park for most of the crowd, and it was a very happy experlence for them.

Developing a Sense of Spiritual Values

No definite time is set aside in the school curriculum for moral or spiritual training. It is the conviction of the faculty of this school that it is impossible to separate moral and apiritual values from the rest of the school curriculum and of dally living. Values are leamed through experlence. It is essentlal to develop a sense of community of interests and of mutual respect among pupils. A sense of honesty and fair play, a spirit of sharing, foeline of respect for others, even where these are different -- all of these are part of the dally values stressed in democratic $11 \mathrm{ving}$. And all of these are incluced in the activities of the school, not in separate, pigeon-holed lessons, but many times and under many clrcumstances. The rundamentals of democratic living are stressed in Elving the puplla opportunity to inltiate profects, to do creative work and to make cholces, whlle also stressing the importance of recoenizing and respecting the cholces of others.

There is no church within the limlts of the school 
district itself, but there are number of churches of several different denominations in the adjecent commnity of Highland park; and the chlldren are always encouraged to attend the church of the1r own choice. On Friday oach teacher rominds the children to go to sunday school or church; and on lizonday count is taken of those who did attend. Most of the chlldren attend falrly regularly.

The chllaren have some form of fiving thanks for meals, usually just before leaving for the lunchroom. Sometimes one child w11l ask for the privilege of returning thanks. One boy during the recent war wrote to the teacher whom he had had in the first grade, telling of a crisls that his outflt had just gone through. He sald that some of the boys praged, and that the only prayer he coula trink of was the one she had taught hlm when they would ask the blessing in her room.

The chlldren of each grade memorlze certain tiblo verses and Psalms. The second Erade chllaren learned the Twenty-third Psalm, the Lord's Prayer, John $3: 16$, the colden fule and parts of the Beatitudes and other pasages. One of the teachers presented a choral program the P.T.A., In which the children repeated from memory the Christmas story as told by st. Luke. 
CONCLUSION 
The precedine pages have shown how both school and community have expanded and adapted during the past twenty-four years, since the founding of the first oneroom school. The history of both has been a continual story of adjustment to chang ing conditions. Throughout Its existence, the school has been thought of as only a temporary comunity school; and it is uncertain vinether it 111 continue as a soparate unit or eventually be absorbed into one of the larger schools.

The comanity itself has been constantig undergolng changes. The establishment of standiford Pleld as an alpport to relieve the congestion of owman Flold, and to allow room for expansion, has cefinitely affected this community; the alrport now comprises 365 acres. During Norld tar II the curtiss-wright Airolane Factory was located noar the school district, and, of course, attracted many workers whose chlldren had to be provided for in school. After the war, this site was occupled by the huEe International Harvester plant costing about $\$ 45,000,000,00$ and employing about 5,000 workers.

Wore recently. the state pair Asoclation has purchased about 382 acres of land in a more or 1038 triangular area bounded by Preston Highway, crittenden Drive. Ph1111pg Lare and the southern Ra1lroad. Tro of 
the first structures scheduled for erection are a threestory atadium with a seating capacity of 50,000 and a collaou with a seating capacit of 20,000. Detweon the times of the annual state Falrs, this plant is to be kept buzzlng wth cultural, educatlonal ard amuserent attractions, football, basketball and other sports.

whe Airport, the state Fair crounds and the industrial plants in this aroa 111 furnish adoltional enployment and 111 up tho additional housing units that are in process of construction; and will, of course. bring adaltional educational responglbilitles.

At the present time the city of Louls ville is makIng plans to annex approximately eleht square miles of adjoining territory. which wil include this school district and several others at present in the county school system. It is hopod that tho children trainod In the small Adalr school w111 be able to take the ir places along with the childwen of the other communities wth whom they may be throw in contact, socially as well as scholastically. Life is a serlos of now adjustments, and now situations merely serve as a test of one's ablilty to naster such adjustments.

\section{Why Teach in a Small Commun ty School?}

Whatever the future may bring, the entire twentyfour years of the existence of Adaly School have been as a small and strugeling community school; and its 
teachers have "stuck of it" ovor the years, for length of service ranglng from three to twenty jears. (The writer has been there for six years.) Every teacher on the faculty has had the question askec her many times: "Why stay in such a small school?" and there have been frequent offers of positions in larger and noro flourishing schools.

Just why should one stay in a small and strugeling combunlty when broader, br Ighter and larger hor zons beckon? This is a ble question and one that is diffcult to anawor categorlcally, since there are so many different answers and opinions from so many different standpolnts. But to answer the question in 1ts broadest sense one might ask. "Why should small town have any laws or town board; why should a emall community have a church in which to worship?" Theso questions would be asy onough to answer if one had to live in a community without these institutions. Since people are living under a democrat ic government, it is just as incumbent upon the teacher to teach in a sall community school as it is to have law enforcement and a place to orship in the small community.

Regardiess of the community in which youth resides, the boys and girls of today w111 be the citizens of tomorrow; and as are the boys and girlo of today. so 111 be the community, town, atate and nation of tomorrow. Then, in order to have a good country in which 
to live, it is the duty and privilege of the teacher to serve the smallor comanitios as well as the larger and wealthler ones.

Some more conc:se and speclfle reasons may be given for teaching in a small community school. In order to be able to give the best arvice to any comunity, it is necessary for the teacher to know the needs of the comaunlts, its rosouces, its probloms, Its interests. Its aocial, economic, political and relislous status. The small community school clves the teacher a eroater opportunity to know the comming moro minutely and thoroughly. The toacher has a much better chance to Isit the puplis and the ir parents in thesr bones, and this enables her to become bettor acquainted with the onvironment under wich the children have bean broueht up and to understand the children better. nd the more she understands the chlldren as IndIvlduals, the more she can help thew to dovalop into better Indivichals.

meen the 10cal situation changes in such a way that the small comunity and sall school are absorbed into larger units, new problems w111 be ralsed; and the cood teacher will find ways to continue to treat chilaren as Individuals rather than to loge the individual in the mass. Zut as lone as the opportunety exlats to work in the smaller undt, with the closer assoclation and the natural tie-up of human relations, no tescher needs to apolosize or to be pitied for teackine in the sinall school or the small community. 
BIBLIOGR AP HY

81 


\section{BIBLIOGRAPHY}

BOOKS

Adans, Fay, Educating Amerlca's Children. New York:

The Ronald Press, 1946. p 242.

Bode, Boyd H., Democracy as A Way of Llfe. Wew York: The vacmilian Co., $1943 . \bar{p} 1 \overline{14}$.

Caswe11, Hollis L., Education in the glementary School. llew York: American Book Co.. 1942. p 32I.

Dewey, John, Experlence and Education. Now York: Tho Nacmllian co.. $1939 . p$. 116.

Dewey, John, Democracy and Education. New York: The Hacmilian Co., 1942. p4I8.

Gwyn, J. Minor, Curriculum Princlples and Soclal Trends. New York: The Macmilian Co., 1947. p 630.

Hacomber, Freman C., Gulding Chlld Development In The Elementary School. New York: American Book co., 1941. p 335.

0lsen, Bdwara G., School And Commun lty. Now York: Pront lce-Hail Co., 1941. p 442.

Schneideman, Rose, Democrat ic Education in Practice. New York and London: Farper Eros., 1945. p 492.

Stratmeyer, Florence B., et. al., Developing a Curriculum For Modern Living. Nov York: Bureaŭ of

Publications Teachers College. Columbia University 1945. p 554 .

\section{PSEIODICALS}

Chase, Lawrence S., "Eetter Parent-Teacher Cooperation Improves Felationships in the Elementary School". The National Elementary Princlpal, Vol. 26 (Apri1, 1947) pp 7-9.

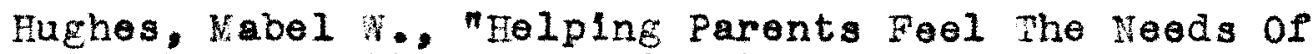
The School", The National Elementary Principal. Vol. 26, (AprTI, I947) pp I2-16.

Kent, James I." "Acquainting the Public with Its Schools", The National Elementary Princlpal. Vol. 26, (December, 1946) pp 21-23. 
Neufelat, Carl, "Incouraging Greater Pupil Particlpation in the operation of the School". The National Elementary principal, Vol. 26, (June, 1047) pp 43-46.

Feese, Sara H., "Respecting the Rights and Oplnions of Others", The National Elementary Princlpal, Vol. 22, (Juiy, I943) pp $331-335$.

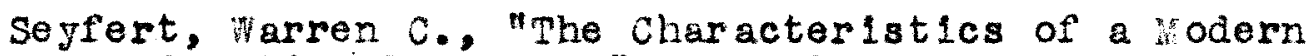
Bducational program", The Blementary School

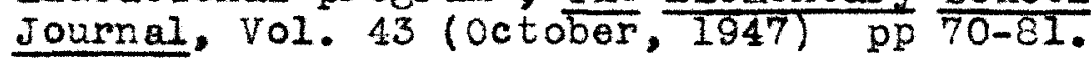

Sinks, Thomas A., "Community Contacts and Experiences that are vital", The National Blementary Princ1pal, Vol. 22, (JuIF, 1943) pp 376-380.

PAUPHLETS, BULLET INS AND YEAR BOOKS

Community Living And The Slementary School, TwentyFourth Yearbook of the National Elementary Princlpal, (september, 1945). p 352.

How To Know And How to Use Your Community, The Department of تIementary School principals, Washington, D. C., 1941-2. p 78 .

Learnine World Goodwill in the Elementary School, Twenty-

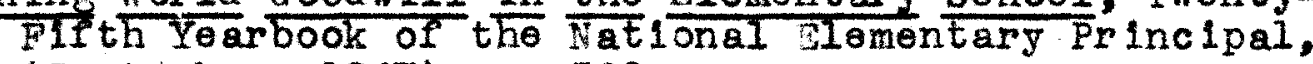
(September, 1947). p 366.

Spiritual Values in the Elementary School. Twenty-Sixth Yearbook of the Irational Elementary Principal. (September, 1947). p 351 .

What Schools Can Do: 101 Patterns of Educational Practices. Report of Metropolitan School study Councll, 525 w. 125th Street, New York. (May, 1947) p 241 . 